\title{
Hay Cave: A 30,000-year cultural sequence from the Mitchell-Palmer limestone zone, north Queensland, Australia
}

\section{Harry Lourandos}

Department of Anthropology, Archaeology and Sociology, School of Arts and Social Sciences, James Cook University, Cairns, Queensland

harry.lourandos@jcu.edu.au

\section{Bruno David}

Monash University, Clayton, Victoria

\section{Nicola Roche}

Umwelt (Australia) Pty Ltd, Toronto, NSW

\section{Cassandra Rowe}

Monash University, Clayton, Victoria

\section{Angela Holden}

University of Queensland, St Lucia, Queensland

\section{Simon J. Clarke}

Charles Sturt University, Wagga Wagga, New South Wales

\section{Introduction}

Hay Cave is one of many limestone caves in the tropical Mitchell-Palmer area of north Queensland. Archaeologically, its major significance is a lengthy, more than 30,000 year-long, cultural sequence, with good preservation of faunal remains as well as stone artefacts and an 
abundance of rock art. Thus, it offers the opportunity to investigate long-term local archaeological trends in one site and to compare these with regional trends obtained from a wider range of sites throughout this archaeologically rich area (David and Lourandos 1997). How can these long-term cultural trends be characterised from an individual site? In what ways do they reflect wider regional trends and patterns? How do they compare with palaeoenvironmental trends? And, at a more general level, how can we connect different spatial scales of investigation (the local or site-specific and the regional) when seeking to explore long-term cultural trends? These were the questions guiding the research.

As a limestone cave with alkaline soils and good preservation, Hay Cave is well endowed in different kinds of archaeological materials, raising also the question of the relationship between different lines of archaeological evidence when exploring cultural trends through time. To what degree does each category of archaeological material represent independent sets of evidence, and to what degree can they be related inter-textually? With such questions in mind, the stone artefacts, animal bone, land-snail shell, mussel shell, brush-turkey egg shell, charcoal and hearths of Hay Cave are examined here in relation to wider regional chronological patterns for Cape York Peninsula (see David and Lourandos 1998). A large number of AMS radiocarbon determinations were obtained to investigate these data in adequate chrono-stratigraphic detail.

\section{The Mitchell-Palmer limestone zone}

The Mitchell-Palmer limestone zone is part of the Chillagoe Formation, located $180 \mathrm{~km}$ northwest of Cairns, north Queensland, Australia (Figure 1). The individual limestone towers ('bluffs') often exceed $1 \mathrm{~km}$ in length and $500 \mathrm{~m}$ in width, jutting up to $150 \mathrm{~m}$ above the surrounding landscape (Figure 2). These are impressive rock formations, possessing regionally distinctive lithologies and sediments (e.g. Galloway et al. 1970; Day et al. 1983:85), vegetation communities (e.g. Galloway et al. 1970) and fauna (for preliminary results, see Hall et al. 1996; Macrokanis 1996; see also Stanisic and Ingram 1998) in an otherwise dry sclerophyll landscape.

The Chillagoe Formation outcrops towards the western margin of the Hodgkinson Province as a steeply dipping, discontinuous belt running parallel to the Palmerville Fault line. The unit extends over a distance of approximately $150 \mathrm{~km}$ and varies in width from $10 \mathrm{~km}$ to a few hundred metres. Regional magnetic imagery indicates that the Chillagoe Formation continues beneath ground cover to the north in a north-northeasterly direction (Domagala and Fordham 1997).

The Chillagoe Formation consists of varying proportions of limestone, chert, basalt, arenite and mudstone, conglomerate and breccia. Limestone is the characteristic lithology. Given the geological components and an estimated early Silurian age (about 428 million years), the limestone belt probably was deposited as calcareous muds and coral reefs; earth movements since deposition have folded and tilted the limestone into its current vertical position. Where erosion has removed the surrounding material, the limestone is now exposed as numerous towers of variable height and size (Domagala and Fordham 1997; Stanisic 1997).

Vegetation on the Chillagoe Formation limestone outcrops is deciduous microphyll vine thicket. This is a stunted vine forest in which the canopy closes at $3 \mathrm{~m}$ to $9 \mathrm{~m}$ above the ground, with the majority of emergents deciduous, together with many understorey species existing as deciduous or semi-evergreen plants. The vine thickets lose their leaves in response to a drop in moisture availability, and the ready supply of leaf litter provided by the vegetation fills the rock crevices to further enhance the water-conserving properties of the limestone outcrops (Kahn and Lawie 1987). Fensham $(1995,1996)$ denoted these vine thickets as a floristically distinct 
group restricted mainly to limestone karst; the limestone substrate forms an additional natural fire barrier. Within the Chillagoe Formation, individual limestone towers are isolated by open woodland eucalypt communities devoid of limestone (Rowe et al. 2001). Climate is semi-arid, with a highly seasonal rainfall regime, falling predominately in the months of December to March. The enhanced humidity-preserving qualities of the limestone outcrops, particularly in caves surrounded by vine thickets, are especially relevant to long-term cultural trends spanning drier and wetter climatic phases, as at Hay Cave (see below).

The limestone outcrops are typically surrounded by alkaline rocky pediments conducive to the preservation of organic materials such as bone, egg shell and land-snail shell. In some rare instances, archaeological excavations have recovered well-preserved late-Holocene wooden digging sticks and other 'soft' organic items in buried cave sediments, including ancient fungus, fig fruit and Pandanus nuts (David and Dagg 1993). Hundreds of shallow rockshelters and also deep caves occur near the junction of the towers and their pediments. Some of these caves extend hundreds of metres into the rock, most often in pitch-black conditions, but also at times illuminated by roof collapses and sinkholes creating skylit chambers. While no evidence of people has ever been found in these deeper recesses, archaeological evidence of Aboriginal occupation is abundant in more open rockshelters and sunlit cave entrances. There is also ample evidence of Aboriginal presence on the plains surrounding the towers, particularly in the form of partly buried and surface stone artefact scatters.

\section{Hay Cave}

Hay Cave is a large limestone cave positioned between the Mitchell and Palmer rivers, towards the northern limits of the Mitchell-Palmer limestone belt and approximately 140 $\mathrm{km}$ west of the eastern Australian coastline, at $16^{\circ} 6^{\prime} \mathrm{S}$ latitude and $144^{\circ} 7^{\prime} \mathrm{E}$ longitude (Figures 1 and 3). The site was recorded during Bruno David's Mitchell-Palmer archaeological site surveys as site number PM18 (being the 18th archaeological site recorded in this programme), and also by the Chillagoe Caving Club under its speleological site number MP118. Hay Cave is situated at the southern end of Wilson's Tower, accessible from the east, with a large entrance (16 $\mathrm{m}$ wide, $3 \mathrm{~m}$ high and $10 \mathrm{~m}$ deep) (Figure 3 ). It sits at the base of the limestone tower, atop a small scree covered in vine thicket that slopes down to a surrounding plain of open sclerophyll forest. The cave entrance itself is positioned slightly above the level of the flat, soft cave floor within the overhang. Sunlight is subdued immediately inside the overhang, towards the centre of the entrance chamber. Here, where the floor is flat and sediments are soft, archaeological excavations were undertaken by Bruno David, Harry Lourandos and Chris Clarkson in 1996 (Figures 3 and 4). Four juxtaposed $50 \times 50 \mathrm{~cm}$ squares were excavated, the deepest of which (M30) was removed in 63 Excavation Units (XU) of mean $2.0 \mathrm{~cm}$ thickness and following Stratigraphic Units (SU) where visible (Figure 5). Twenty-two distinct SUs were identified in the deepest excavation square of $133 \mathrm{~cm}$ depth. Sediments containing cultural materials were found at all depths except within the thick clays of SU3 at the very base of the excavations (Table 1).

The four Hay Cave squares were excavated independently of each other. Cultural items $>2$ $\mathrm{cm}$ maximum length were plotted in three dimensions and drawn on individual XU recording forms during the course of the excavation. All other sediments were sieved in $3 \mathrm{~mm}$ mesh sieves and bagged for later sorting in the laboratory. Sediment samples were collected from the $<3 \mathrm{~mm}$ residue from each $\mathrm{XU}$ of each square.

At the University of Queensland and Monash University, over the ensuing years Angela Holden (1999) worked on the stone artefacts; Nicola Roche (1999) on the animal bone following preliminary work by Neville Terlich (1998); Cassandra Rowe (1998) on the land- 
snail shell; Simon Clarke (2005) on the egg shell; and Bruno David (e.g. David et al. 1997) on the rock art and chrono-stratigraphy. This, however, is the first full site report to appear and to assemble the different lines of previously unpublished evidence to explore long-term temporal trends.

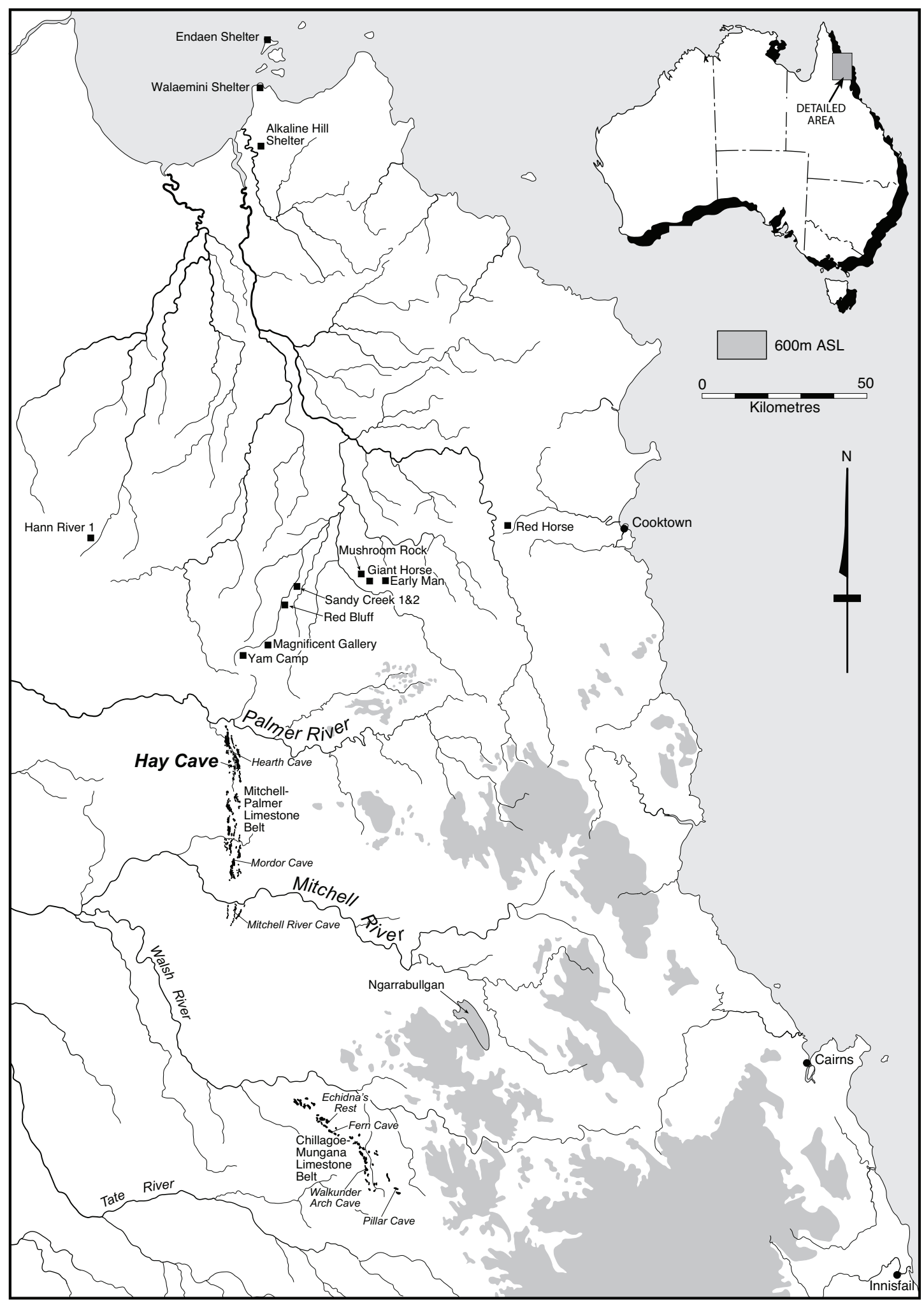

Figure 1. Map of southeast Cape York Peninsula showing location of the individual Mitchell-Palmer and Chillagoe-Mungana limestone towers and the excavated archaeological sites. 


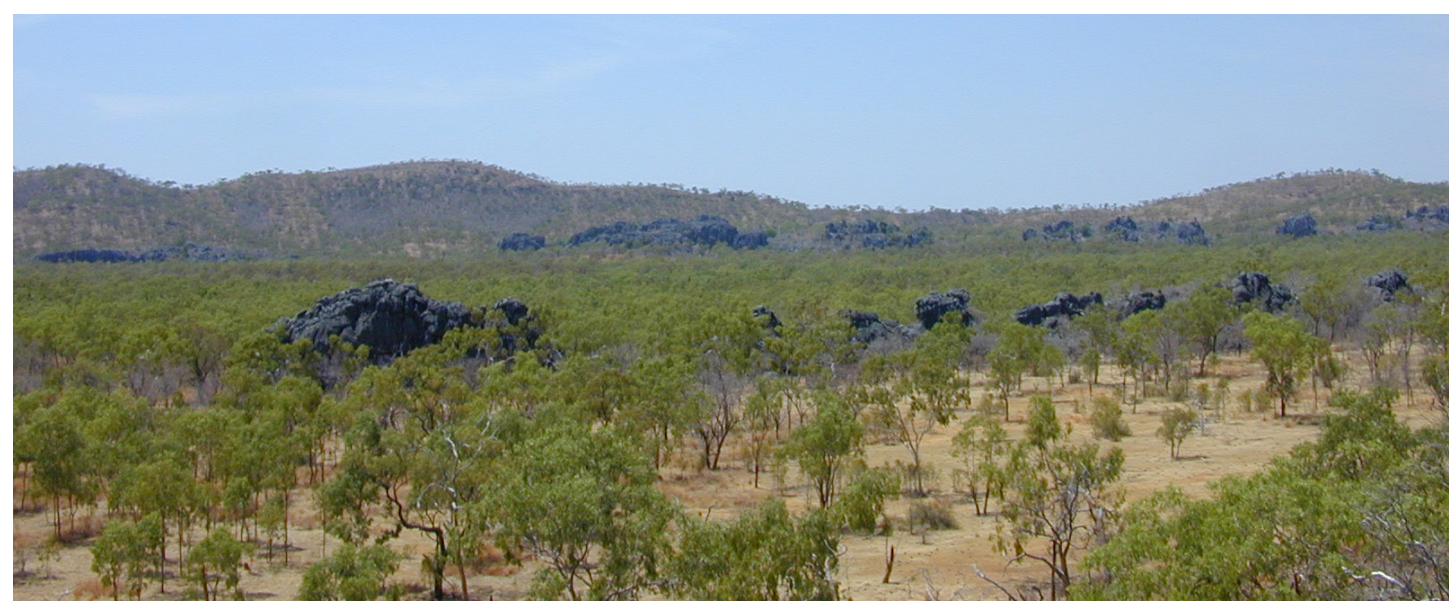

Figure 2. Limestone towers of the Mitchell-Palmer limestone zone.

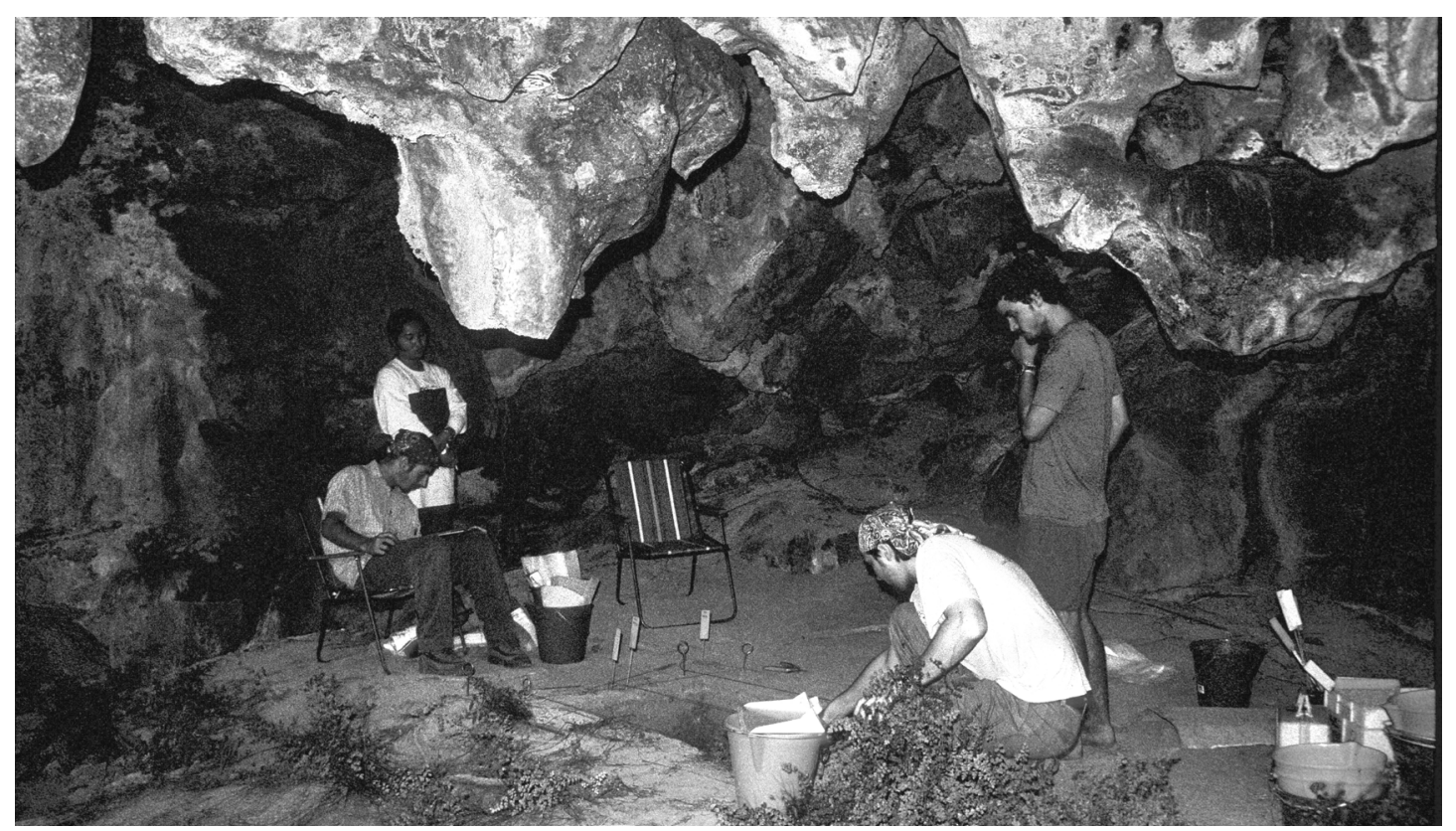

Figure 3. Hay Cave, excavation in progress.

\section{The sediments}

Three major SU were revealed during the excavation (Figure 5). SU1, the uppermost, is subdivided into 18 subunits (SU1a-SU1r). All subunits of SU1 are ashy, and at least seven welldemarcated hearths are represented. The latter appear in SU1b/1c; SU1d/1f; SU1e/1h/1i/1k; SU1j; SU1m; SU1n; SU1q; and also probably SU1o. The other SU1 subunits are either of ill-defined hearths or contain mixed ashy sediments from hearths lying above or from those extending beyond the excavated deposits (SU1a, the ashy treadage zone; SU11; SU1p; SU1r). Thus, the entire period spanned by SU1, the uppermost unit, represents the intensive construction of hearths within this part of the site.

SU2, lying immediately below SU1, is divided into three subunits (SU2a, 2b and 2c), each predominantly composed of silt and clay and variably rich in calcium carbonate concretions. No in situ evidence of hearths has been recovered from this unit.

SU3, the lowermost unit, is highly compact and clayey. Again, no stratigraphic evidence of hearths has been recovered from this unit.

Each SU is described in greater detail in Table 2. 

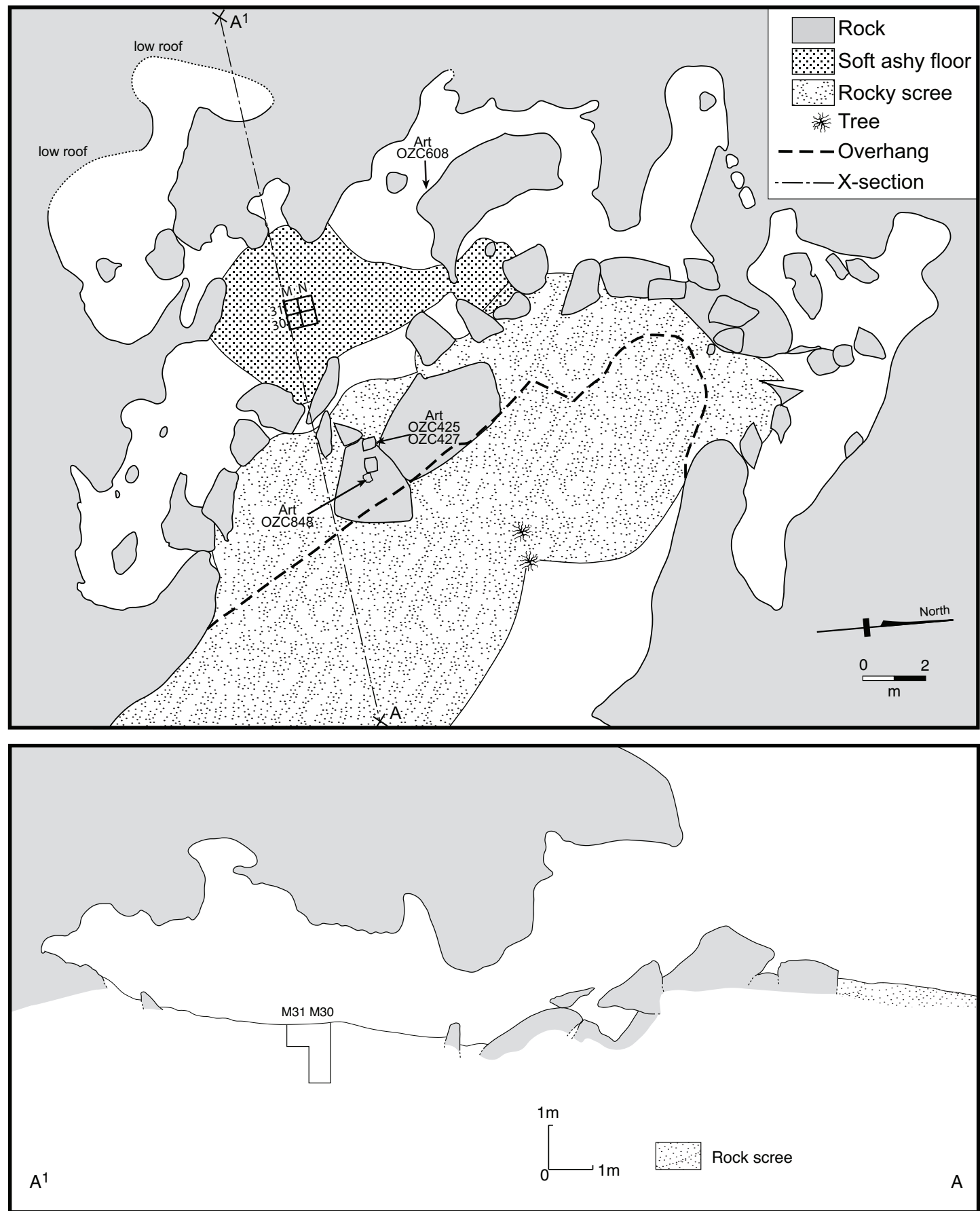

Figure 4. Map (top) and cross-section (bottom) of Hay Cave showing location of excavation squares and radiocarbon-dated rock art.

\section{Radiocarbon dates}

Twenty-six radiocarbon determinations have been obtained from Hay Cave. All are AMS dates, most on single pieces of charcoal ( $\mathrm{N}=15)$, the others from single pieces of Alectura lathami egg shell $(\mathrm{N}=3)$, freshwater mussel shell $(\mathrm{N}=4)$, or from scrapings from charcoal wall drawings $(\mathrm{N}=4)$. The radiocarbon dates were obtained from three laboratories, ANSTO (OZ numbers, 24 dates), University of Colorado INSTAAR (NSRL- number, 1 date) and Waikato (Wknumber, 1 date). All the excavated radiocarbon samples were obtained from Square M30.

From the deepest excavated levels, a near-basal date was obtained on a riverine bivalve shell recovered from XU60 (122-125 cm below the surface). The resulting date of 29,700 \pm $1100 \mathrm{BP}$ (OZD948) indicates that cultural sediments towards the base of the excavation were 


\section{EAST}

$\mathrm{cm}$

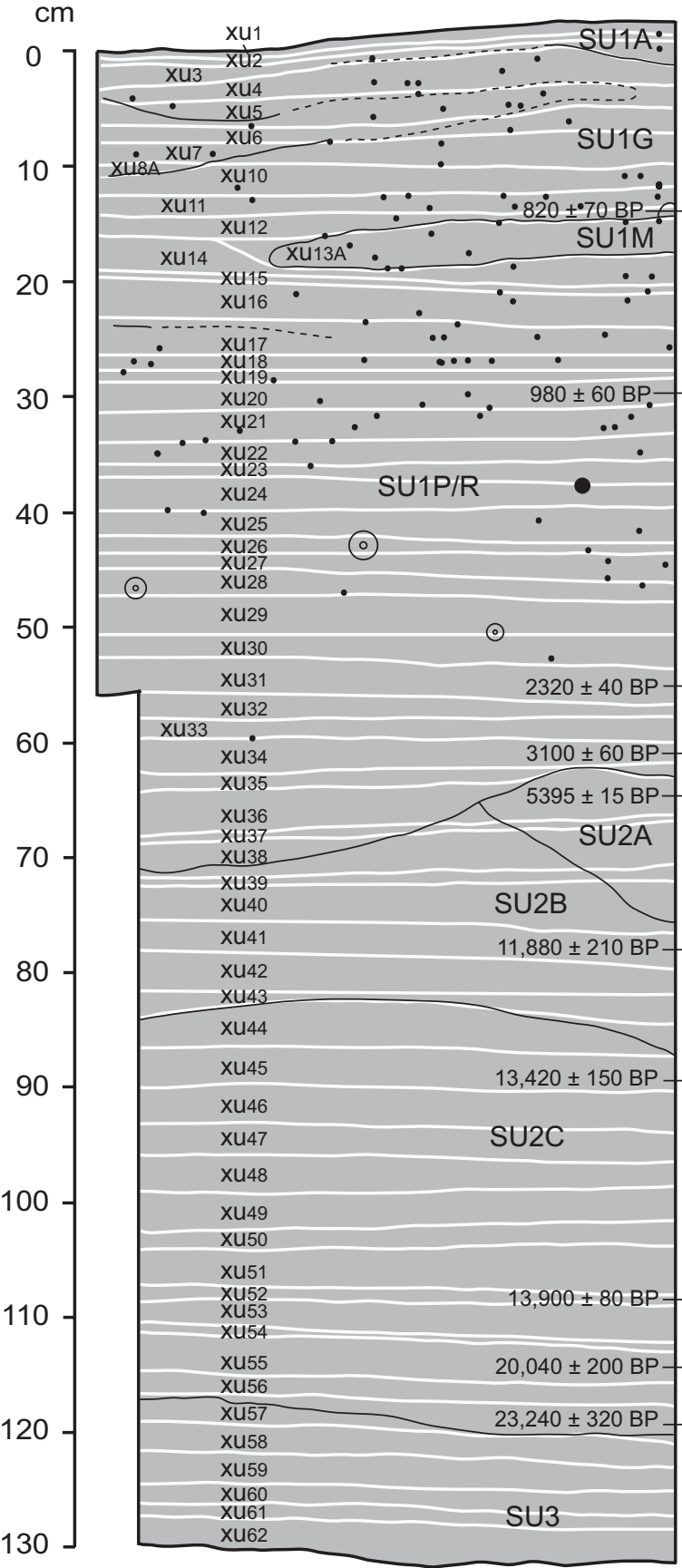

(0) root charcoal $\longrightarrow$ rock
SOUTH

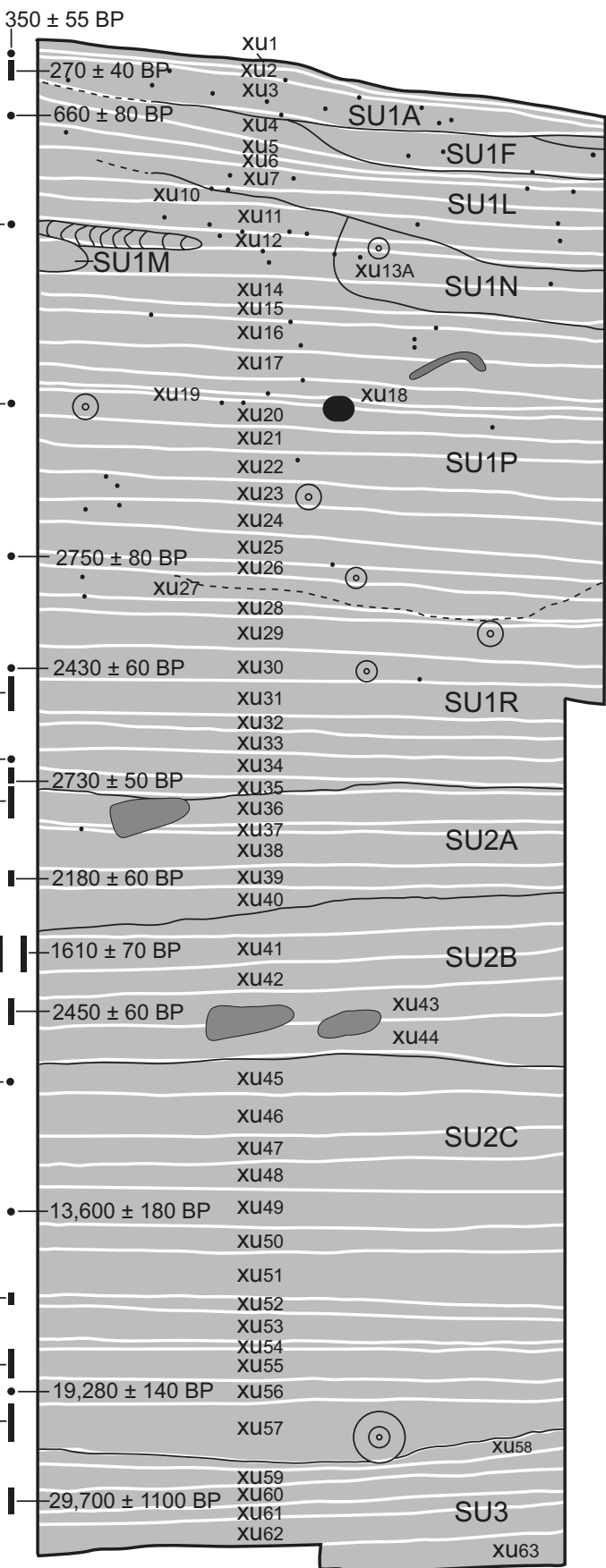

Figure 5. East and south sections, Square M30.

deposited around 30,000 years ago. A small number of artefacts also occur at the SU2-SU3 interface. Below this lowermost radiocarbon date, however, the SU3 sediments themselves are of very compact mottled clays, with small manganese nodules that appear to pre-date human occupation.

Radiocarbon dates were obtained from every three or so XU above XU60, sometimes more frequently. They appear to progress at a fairly regular sedimentation rate of about 0.10 $\mathrm{cm} / 100$ years from ca. 30,000 BP in XU60 to 13,900 BP in XU52 (see Table 3). After this time, sedimentation rates increase two- to three-fold, to $0.26 \mathrm{~cm} / 100$ years, until ca. $3000 \mathrm{BP}$ 
Table 1. Excavation details, Hay Cave Square M30.

\begin{tabular}{|c|c|c|c|c|c|}
\hline $\mathbf{X U}$ & SU & $\begin{array}{l}\text { Volume } \\
\text { (litres) }\end{array}$ & $\begin{array}{l}\text { Weight } \\
\text { (kg) }\end{array}$ & $\begin{array}{l}\text { Area } \\
\left(m^{2}\right)\end{array}$ & $\begin{array}{c}\text { Mean thickness } \\
\text { (cm) }\end{array}$ \\
\hline 1 & $1 a$ & 0.5 & 0.25 & 0.25 & 0.1 \\
\hline 2 & $1 a$ & 4.5 & 4 & 0.25 & 1.3 \\
\hline 3 & $1 a$ & 6 & 6 & 0.25 & 1.8 \\
\hline 4 & $1 a+1 d+1 \mid$ & 5 & 5 & 0.25 & 1.7 \\
\hline 5 & $1 f+1 \mid$ & 4.5 & 5 & 0.25 & 1.4 \\
\hline 6 & $1 f+1 \mid$ & 5 & 5 & 0.25 & 1.8 \\
\hline 7 & $1 \mid+1 p$ & 5.5 & 5.5 & 0.25 & 2.2 \\
\hline $8 a$ & 11 & 1 & 1.25 & 0.12 & 0.9 \\
\hline $9 a$ & 11 & $<0.5$ & 0.25 & 0.005 & 0.7 \\
\hline 10 & $1 \mid+1 p$ & 5.5 & 5.5 & 0.25 & 1.7 \\
\hline 11 & $1 \mid+1 n+1 p$ & 6 & 5.25 & 0.25 & 2.0 \\
\hline 12 & $1 \mid+1 n+1 p$ & 5 & 5 & 0.25 & 1.5 \\
\hline $13 a$ & $1 m+1 n+1 p$ & 3 & 3 & 0.15 & 1.8 \\
\hline 14 & $1 n+1 p$ & 5 & 4.75 & 0.25 & 2.3 \\
\hline 15 & $1 p$ & 5 & 5 & 0.25 & 1.7 \\
\hline 16 & $1 p$ & 6 & 6 & 0.25 & 2.6 \\
\hline 17 & $1 p$ & 5.5 & 5.5 & 0.25 & 2.2 \\
\hline 18 & $1 p$ & 4 & 4.5 & 0.25 & 1.4 \\
\hline 19 & $1 p$ & 1 & 1.5 & 0.25 & 0.7 \\
\hline 20 & $1 p$ & 6 & & 0.25 & 2.8 \\
\hline 21 & $1 p$ & 6 & 6 & 0.25 & 2.2 \\
\hline 22 & $1 p$ & 5.5 & 6 & 0.25 & 2.5 \\
\hline 23 & $1 p$ & 5 & 4.5 & 0.25 & 1.9 \\
\hline 24 & $1 p$ & 6 & 6.5 & 0.25 & 2.8 \\
\hline 25 & $1 p$ & 6 & 6 & 0.25 & 2.1 \\
\hline 26 & $1 p$ & 5 & 5 & 0.25 & 1.6 \\
\hline 27 & $1 p+1 r$ & 7 & 6.5 & 0.25 & 2.0 \\
\hline 28 & $1 \Gamma$ & 4.5 & 4 & 0.25 & 1.2 \\
\hline 29 & 1ז & 7 & 7 & 0.25 & 3.3 \\
\hline 30 & $1 \Gamma$ & 6.5 & 7 & 0.25 & 2.7 \\
\hline 31 & 1ז & 6.5 & 7 & 0.25 & 2.7 \\
\hline 32 & 1ז & 5 & 5 & 0.25 & 1.6 \\
\hline 33 & $1 ז$ & 5 & 5.5 & 0.25 & 2.0 \\
\hline 34 & 1ז & 5 & 6.5 & 0.25 & 2.3 \\
\hline 35 & $2 a$ & 3.5 & 4 & 0.25 & 1.4 \\
\hline 36 & $2 a$ & 6.5 & 7.5 & 0.25 & 2.5 \\
\hline 37 & $2 a$ & 4 & 5.5 & 0.25 & 1.1 \\
\hline 38 & $2 a$ & 6 & 8 & 0.25 & 3.2 \\
\hline 39 & $2 a$ & 4 & 4.5 & 0.25 & 1.6 \\
\hline 40 & $2 a+2 b$ & 7.5 & 9 & 0.25 & 2.9 \\
\hline 41 & $2 b$ & 8 & 9 & 0.25 & 2.9 \\
\hline 42 & $2 b$ & 7.5 & 8.5 & 0.25 & 2.7 \\
\hline 43 & $2 b$ & 7 & 9.5 & 0.25 & 3.0 \\
\hline 44 & $2 b$ & 6 & 8 & 0.25 & 2.7 \\
\hline 45 & $2 c$ & 8 & 9.5 & 0.25 & 3.2 \\
\hline 46 & $2 c$ & 8.5 & 10 & 0.25 & 3.9 \\
\hline 47 & $2 c$ & 6.5 & 8 & 0.25 & 2.2 \\
\hline 48 & $2 c$ & 6.5 & 8 & 0.25 & 2.7 \\
\hline 49 & $2 c$ & 9 & 10 & 0.25 & 3.3 \\
\hline
\end{tabular}


Table 1. Continued

\begin{tabular}{|c|c|c|c|c|c|}
\hline XU & SU & $\begin{array}{l}\text { Volume } \\
\text { (litres) }\end{array}$ & $\begin{array}{l}\text { Weight } \\
\text { (kg) }\end{array}$ & $\begin{array}{l}\text { Area } \\
\left(\mathrm{m}^{2}\right)\end{array}$ & $\begin{array}{l}\text { Mean thickness } \\
(\mathrm{cm})\end{array}$ \\
\hline 50 & $2 c$ & 6.5 & 8 & 0.25 & 2.4 \\
\hline 51 & $2 c$ & 9 & 11 & 0.25 & 3.2 \\
\hline 52 & $2 c$ & 3.5 & 5 & 0.25 & 1.6 \\
\hline 53 & $2 c$ & 4.5 & 6 & 0.25 & 2.0 \\
\hline 54 & $2 c$ & 4 & 5.5 & 0.25 & 1.4 \\
\hline 55 & $2 c$ & 6 & 7.5 & 0.25 & 2.7 \\
\hline 56 & $2 c$ & 4 & 5.5 & 0.25 & 2.1 \\
\hline 57 & $2 c$ & 4.5 & 5.5 & 0.25 & 2.3 \\
\hline 58 & 3 & 5 & 5.5 & 0.25 & 1.8 \\
\hline 59 & 3 & 6 & 8 & 0.25 & 1.9 \\
\hline 60 & 3 & 6 & 7.5 & 0.25 & 2.5 \\
\hline 61 & 3 & 5 & 5.5 & 0.25 & 1.1 \\
\hline 62 & 3 & 4 & 4.5 & 0.25 & 1.6 \\
\hline 63 & 3 & 3 & 3 & 0.18 & 1.4 \\
\hline
\end{tabular}

Table 2. Description of Stratigraphic Units, Hay Cave.

SU

Very fine-textured surface sediments. Dry and ashy, fairly compact but unconsolidated and very easy to dig. Treadage zone of surface-disturbed sediments are extremely shallow, restricted to the uppermost 1-2 mm. This disturbed veneer consists of sediments indistinguishable in colour, content and texture from the rest of this Su. Cultural materials noticed during excavation.

Thin lens of light brownish brown heat-baked sediment. Its boundary with overlying SU1a is sharp, as it is also with underlying SU1C.

1b This SU is not present across all the excavated squares, being of limited spatial extent: it is only present in the NW corner of the four-square pit. Sediments are homogeneous throughout.

Sediments are very ashy and cultural in origin. They are discontinuous across the four squares, being present only in the NW part of the excavation, immediately below SU1b but with a slightly greater spatial spread. Where SU1b does not occur, SU1c merges with SU1a. The interface between SU1c and SU1b is marked in most parts. The interface between SU1c and Su1e below it occurs over a vertical distance of ca. $1 \mathrm{~cm}$. Sediments are very dry.

A thin lens of ash towards the southern wall near the Sw corner of Square M30. Sediments are very fine in texture, dry, easy to dig but somewhat compact. The boundaries between su1d and surrounding sediments are marked.

Very ashy lens. Sediments vary in colour from very pale brown in the SW parts of the pit to light brownish grey in the NW parts. This change in colour is gradual; a more reddish appearance of sediments towards the southern side of the pit is consistent with

1e similar patterning in the immediately underlying SUs. SU1e is very fine in texture, dry, somewhat compact but easy to dig. Boundaries between SU1e and surrounding SUs are gradual but easily recognisable in situ and/or on the exposed sections, occurring over a vertical distance of ca. $2 \mathrm{~cm}$.

\section{$\mathrm{pH}$}

Dry Munsell

9

10YR6/2 to 10YR6/3

Light brownish grey to pale brown

8.5

10YR6/4

Light brownish brown

8.5

10YR6/2

Light brownish grey

8.5

10YR8/1

White

8.5

10YR7/3 (SW parts of pit)

to

10YR6/2 (NW parts of pit)

Very pale brown to light brownish grey 
Table 2. Continued

SU

A small lens of colour-stained sediments immediately underlying SU1d. SU1f should not be interpreted as a distinct depositional unit, but rather the heat-stained sediments located immediately

if below the hearth represented by SU1d. Boundaries between SU1f and SU1a, and those between SU1f and SU1d, are marked. Boundaries between SU1f and SU1g are gradual, taking place over a vertical distance of $4-6 \mathrm{~cm}$.

Dry and ashy sediments. While sediments are generally light brownish grey, towards the SW corner of the pit they become more reddish in colour (pink to light brown in Munsell terms). This more reddish towards the SW corner of the pit appears to be the result 19 of the overlying hearth SU1e, which is most pronounced in this area. In this SW corner, the boundary between SU1e and SU1g is marked. The boundaries between SU1g and underlying SU1h and su1i are also marked. SU1g was noticed to contain cultural materials during excavation.

A small, localised lens of dry sediments immediately above SU1i. Like SU1f and SU1k, SU1h is interpreted as a reddish, heat-stained sediment, rather than as a distinct depositional unit. It is inter-

$1 \mathrm{~h}$ preted as a localised, heat-stained lower part of the SU1g hearth. The boundary between SU1g and SU1h is gradual, occurring over a vertical distance of $2 \mathrm{~cm}$. The boundary with overlying SU1i is marked.

A very clearly demarcated hearth, including a fire pit intruding into underlying SU1k, SU1l and SU1p. SU1i is very well-defined throughout, and contains hearth stones. Sediments are white to

1i light grey in colour, interspersed with light grey ash. SU1i contains very large pieces of charcoal randomly distributed throughout. This hearth is most evident in the western part of the pit where the western section dissects it in half.

A localised lens of ash. This unit is a hearth whose boundaries are

$1 \mathrm{j}$ for the most part well-defined. Sediments are dry ash and very fine in texture.

A localised patch of heat-stained sediments immediately below SU1i. It should not be interpreted as a distinct depositional unit, but rather as part of the SU1l sediments that were fire-stained by the overlying SU1i. Boundaries with SU1I and SU1p are gradual; the SU1k-SU1p interface is ca. $2 \mathrm{~cm}$ thick. Sediments are dry and ashy with a reddish tinge.

Sediments are dry, very fine, ashy and homogeneous throughout. Boundary with underlying SU1p is extremely gradual, occurring over a vertical distance of ca. $3 \mathrm{~cm}$. Sediments were noticed to possess cultural materials during excavation.

Apart from a difference in colour, the descriptions of SU1j apply here also.

Relatively unconsolidated ash. Boundaries with surrounding sediments are fairly well-defined in most places, but not sharp, occurring over a distance of $1-2 \mathrm{~cm}$. Numerous roots and rootlets occur in this SU. Sediments are dry. SU1n is interpreted as a hearth.

Sediments are fine and ashy. They are very similar to those of SU1g, but here they occur below SU1j and above SU1p. SU10 is indistinct and appears to be another ash-rich unit which only occurs

10 in the extreme NE corner of the pit. It is probably the very edge of a hearth which remains in situ beyond the excavated pit. The boundaries of this SU are ill-defined and merge with surrounding units over a distance of $2 \mathrm{~cm}$.
pH

Dry Munsell

8.5

10 YR5 $/ 3$

Brown

10YR6/2 to 7.5YR6/4-7.5YR7/4

8.5 Light brownish grey to light brown to pink

8.5

10YR6/1

Pale brown

10YR7/1-10YR8/1 with patches of 10YR7/2

White to light grey

8.5

2.5 YR8/0 to 10 YR8/1

white

8.5

10YR6/3-10YR6/4

Light yellowish brown to pale brown

8.5

10YR6/2

Light brownish grey

8.5

10YR7/1

Light grey

8.5

10YR6/2

Light brownish grey

10YR6/2

Light brownish grey 
Table 2. Continued

SU

This unit is relatively homogeneous and thick compared with those above it. Its boundaries with surrounding SUs are always gradual, 1p taking place over $2-4 \mathrm{~cm}$, with the noticeable exception its boundary with SU1i, which is relatively marked. SU1p is very ashy and fine-grained in texture.

An uneven unit consisting of well-defined patches of white ash interspersed among brown sediments reminiscent of SU1p and SU1r. SU1q is here treated as a single SU with patches of ash constrained within the limits of this SU. SU1q is interpreted as a hearth whose patches of ash have been intermixed (probably largely during hearth construction and use), with sediments of SU1p and SU1r character. Note that both the white and brown components of SU1q are ashy. While the boundaries of SU1q are ill-defined, in the sense that the patches of ash appear interspersed among the brown sediments, the overall area where the ash occurs is very well-defined.

Ashy silt whose boundary with overlying SU1p is gradual and occurs over ca. $5 \mathrm{~cm}$. The boundary with underlying Su2a occurs over

1r $\quad 2 \mathrm{~cm}$. Sediments in SU1r are noticeably less ashy and more brown than those above. They are also noticeably more compact and slightly more humid.

Slightly moist clayey silt, rich in calcium carbonate concretions.

2a This SU represents a major stratigraphic break from overlying SUs. The boundary with underlying SU2b is ill-defined.

Sediments are similar to those of SU2a, but boundaries with surrounding SUs are less well-defined but still occur over some $2 \mathrm{~cm}$ of depth. The major difference from SU2a is that SU2b contains lower concentrations of calcium carbonate concretions. Sediments are fine, clayey silt, somewhat moist.

Silty clay. Sediments are moist and become more clayey with depth. They are relatively homogeneous throughout the pit, and some calcium carbonate concretions occur throughout. The boundary with the overlying SU2b is fairly distinct. Sediments are compact throughout. There is a large root which grows at the interface of SU2C and SU3.

This is the lowermost SU excavated, and appeared to be culturally sterile at the time of excavation (i.e. no cultural materials were noticed in situ). It consists of clayey matrix with large amounts of small manganese nodules $(<1 \mathrm{~cm}$ in diameter). Sediments are

3 mottled and extremely compact. In the western part of the pit, sediments are mottled whitish, but this is less apparent in the eastern part of the pit. Sediments in SU3 were very difficult to dig due to their high moisture content and their very compact nature. The interface between SU3 and overlying SU2c is marked.

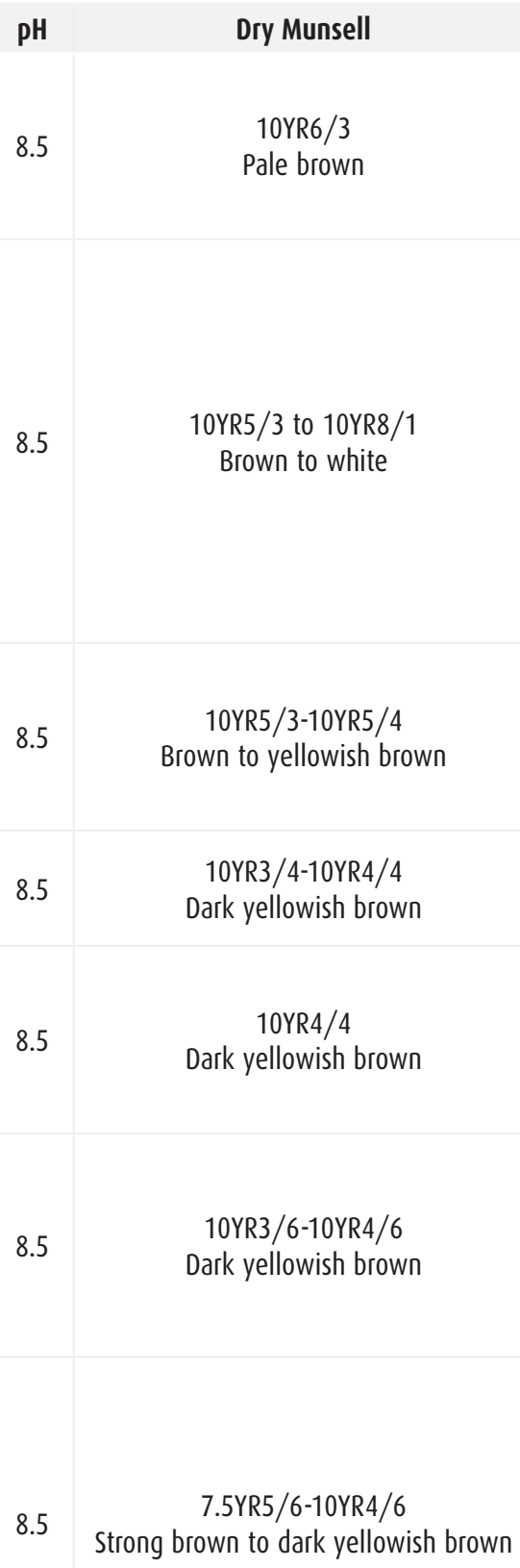

pH

8.5

Dry Munsell

10YR6/3

Pale brown

10YR5/3 to 10 YR8 $8 / 1$

Brown to white

10YR5/3-10YR5/4

Brown to yellowish brown

10YR3/4-10YR4/4

Dark yellowish brown

10YR4/4

Dark yellowish brown

10YR3/6-10YR4/6

Dark yellowish brown

7.5YR5/6-10YR4/6

Strong brown to dark yellowish brown

in XU41. Considerable mixing of sediments, however, is apparent from XU43 to XU35 (as is evident from dating reversals), making it more difficult to interpret average sedimentation rates on this part of the curve. The past 3000 years $\mathrm{BP}$ witnessed a further sustained nine- to 10-fold increase in sedimentation rates, to an average of $2.53 \mathrm{~cm} / 100$ years. The uppermost radiocarbon dates are consistent with the site finally being used by people around the time of European arrival in the region during the late 19 th century AD.

We interpret the zone of dating reversals, most pronounced from $83 \mathrm{~cm}$ to $63 \mathrm{~cm}$ below ground (XU43-XU35), in two ways. This zone represents the boundary between SU1 and SU2 into SU2a and SU2b. Firstly, these levels include the early-Holocene period, a time when other archaeological sequences in north Queensland are also characterised by dating reversals and coarser sediments that have been argued by various authors (e.g. David and Chant 1995) 

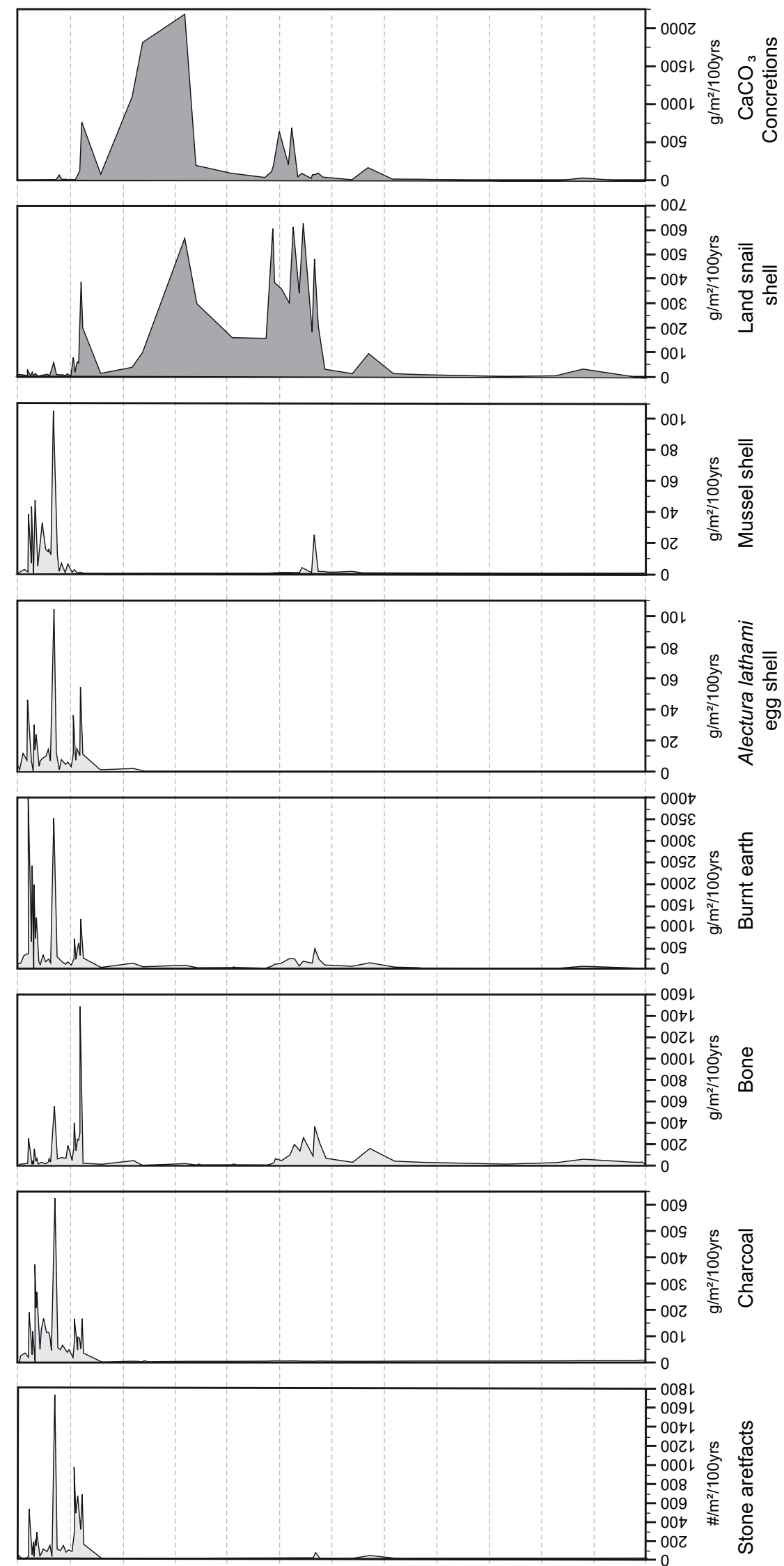

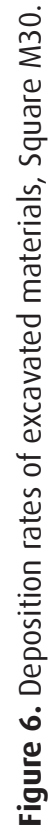


Table 3. Radiocarbon dates from Hay Cave Square M30. Calibrations made on Calib 6.0 (Stuiver and Reimer 1993), using the SH Atmosphere option (McCormac et al. 2004); calibrated years in bold represent highest age probability range at 2 sigma.

\begin{tabular}{|c|c|c|c|c|c|c|c|}
\hline XU & Depth (cm) & Material & $\begin{array}{l}\text { Sample } \\
\text { code }\end{array}$ & $\begin{array}{l}\delta^{13} \mathrm{C} \\
(\% 0)\end{array}$ & $\begin{array}{l}\text { Conven- } \\
\text { tional } \\
\text { radiocarbon } \\
\text { age } \\
\text { (years BP, } \pm \\
1 \sigma)\end{array}$ & 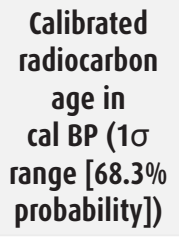 & $\begin{array}{c}\text { Calibrated } \\
\text { radiocarbon } \\
\text { age in } \\
\text { cal BP ( } 2 \sigma \\
\text { range [ } 95.4 \% \\
\text { probability]) }\end{array}$ \\
\hline 2 & 1.4 & charcoal & Wk-6053 & $-26.4 \pm 0.2$ & $350 \pm 55$ & $\begin{array}{l}311-338 \\
(20.9 \%) \\
355-449 \\
(79.1 \%)\end{array}$ & $\begin{array}{c}285-495 \\
(100 \%)\end{array}$ \\
\hline 3 & $1.3-3.1$ & egg shell & OZF619 & -8.5 & $270 \pm 40$ & $\begin{array}{l}153-173 \\
(20.9 \%) \\
177-209 \\
(27.0 \%) \\
277-316 \\
(52.0 \%)\end{array}$ & $\begin{array}{l}145-223 \\
(41.8 \%) \\
260-332 \\
(44.6 \%) \\
364-443 \\
(13.6 \%)\end{array}$ \\
\hline 6 & 8.1 & charcoal & $0 Z 0006$ & -25.14 & $660 \pm 80$ & $\begin{array}{c}552-650 \\
(100 \%)\end{array}$ & $\begin{array}{c}\mathbf{5 0 5}-\mathbf{6 8 5} \\
(99.4 \%) \\
709-714(0.6 \%)\end{array}$ \\
\hline 12 & 17.1 & charcoal & OZD007 & -30.22 & $820 \pm 70$ & $\begin{array}{l}660-762 \\
(100 \%)\end{array}$ & $\begin{array}{c}563-602(6.8 \%) \\
628-807 \\
(89.9 \%) \\
879-901(3.3 \%)\end{array}$ \\
\hline 20 & 30.1 & charcoal & 0ZD939 & -26.77 & $980 \pm 60$ & $\begin{array}{c}794-915 \\
(100 \%)\end{array}$ & $\begin{array}{c}\mathbf{7 3 3 - 9 3 5} \\
(98.4 \%) \\
943-955(1.6 \%)\end{array}$ \\
\hline 26 & 45.7 & charcoal & 0ZD008 & -27.18 & $2570 \pm 80$ & $\begin{array}{c}2488-2644 \\
(66.1 \%) \\
2654-2738 \\
(33.9 \%)\end{array}$ & $\begin{array}{c}2362-2748 \\
(100 \%)\end{array}$ \\
\hline 30 & 53.0 & charcoal & $0 Z 0940$ & -26.49 & $2430 \pm 60$ & $\begin{array}{c}2337-2490 \\
(89.4 \%) \\
2643-2672 \\
(10.6 \%)\end{array}$ & $\begin{array}{c}2209-2223 \\
(0.9 \%) \\
2308-2619 \\
(84.1 \%) \\
2631-2709 \\
(15.1 \%)\end{array}$ \\
\hline 31 & $53.2-55.9$ & egg shell & 0ZF620 & -7.2 & $2320 \pm 40$ & $\begin{array}{c}2180-2240 \\
(55.9 \%) \\
2303-2342 \\
(44.1 \%)\end{array}$ & $\begin{array}{c}2153-2276 \\
(63.0 \%) \\
2290-2349 \\
(37.0 \%)\end{array}$ \\
\hline 34 & 63.5 & charcoal & 0ZD009 & -25.26 & $3100 \pm 60$ & $\begin{array}{c}3164-3185 \\
(9.5 \%) \\
3205-3355 \\
(90.5 \%)\end{array}$ & $\begin{array}{c}3043-3046 \\
(0.2 \%) \\
3063-3393 \\
(99.8 \%)\end{array}$ \\
\hline 35 & $61.8-63.2$ & charcoal & $0 Z D 941$ & -26.96 & $2730 \pm 50$ & $\begin{array}{c}2748-2801 \\
(73.1 \%) \\
2817-2844 \\
(26.9 \%)\end{array}$ & $\begin{array}{c}2721-2882 \\
(99.0 \%) \\
2910-2919 \\
(1.0 \%)\end{array}$ \\
\hline 36 & $63.2-65.7$ & egg shell & NSRL-14448 & -5.0 & $5395 \pm 15$ & $\begin{array}{c}6020-6079 \\
(47.1 \%) \\
6111-6155 \\
(39.8 \%) \\
6174-6189 \\
(13.1 \%)\end{array}$ & $\begin{array}{c}6000-6208 \\
(98.5 \%) \\
6253-6261 \\
(1.5 \%)\end{array}$ \\
\hline
\end{tabular}


Table 3. Continued

\begin{tabular}{|c|c|c|c|c|c|c|c|}
\hline XU & Depth $(\mathrm{cm})$ & Material & $\begin{array}{l}\text { Sample } \\
\text { code }\end{array}$ & $\begin{array}{l}\delta^{13} \mathrm{C} \\
(\% 0)\end{array}$ & $\begin{array}{l}\text { Conven- } \\
\text { tional } \\
\text { radiocarbon } \\
\text { age } \\
\text { (years BP, } \pm \\
1 \sigma \text { ) }\end{array}$ & 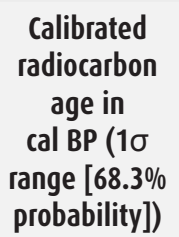 & $\begin{array}{l}\text { Calibrated } \\
\text { radiocarbon } \\
\text { age in } \\
\text { cal BP }(2 \sigma \\
\text { range [ } 95.4 \% \\
\text { probability]) }\end{array}$ \\
\hline 39 & $70.0-71.6$ & charcoal & $0 Z D 942$ & -25.61 & $2180 \pm 60$ & $\begin{array}{c}2000-2155 \\
(88.2 \%) \\
2270-2295 \\
(11.8 \%)\end{array}$ & $\begin{array}{c}1949-1963 \\
(1.7 \%) \\
1967-2213 \\
(77.6 \%) \\
2218-2310 \\
(20.7 \%)\end{array}$ \\
\hline 41 & $74.5-77.4$ & charcoal & 0ZD010 & -24.82 & $1610 \pm 70$ & $\begin{array}{c}1379-1524 \\
(100 \%)\end{array}$ & $\begin{array}{c}1305-1570 \\
(98.5 \%) \\
1583-1600 \\
(1.5 \%)\end{array}$ \\
\hline 41 & $74.5-77.4$ & charcoal & $0 Z 0943$ & -25.0 & $11,880 \pm 210$ & & \\
\hline 43 & $80.1-83.1$ & charcoal & 0ZD944 & -26.92 & $2450 \pm 60$ & $\begin{array}{c}2345-2492 \\
(83.1 \%) \\
2602-2608 \\
(1.9 \%) \\
2641-2678 \\
(15.0 \%)\end{array}$ & $\begin{array}{c}2333-2619 \\
(82.2 \%) \\
2632-2708 \\
(17.8 \%)\end{array}$ \\
\hline 45 & 90.7 & charcoal & OZD011 & -26.37 & $13,420 \pm 150$ & & \\
\hline 49 & 102.8 & charcoal & $0 Z C 422$ & $\begin{array}{l}\text { assumed } \\
-25.00\end{array}$ & $13,600 \pm 180$ & & \\
\hline 52 & $106.7-108.2$ & charcoal & $0 Z D 945$ & -27.11 & $13,900 \pm 80$ & & \\
\hline 55 & $111.6-114.3$ & $\begin{array}{l}\text { freshwater } \\
\text { mussel shell }\end{array}$ & $0 Z D 946$ & -5.68 & $20,040 \pm 200$ & & \\
\hline 56 & 118.2 & $\begin{array}{l}\text { freshwater } \\
\text { mussel shell }\end{array}$ & 0ZD012 & -5.35 & $19,280 \pm 140$ & & \\
\hline 57 & $116.4-118.7$ & $\begin{array}{l}\text { freshwater } \\
\text { mussel shell }\end{array}$ & 0ZD947 & -9.41 & $23,240 \pm 320$ & & \\
\hline 60 & $122.4-125.0$ & $\begin{array}{l}\text { freshwater } \\
\text { mussel shell }\end{array}$ & 0ZD948 & -9.09 & $\begin{array}{c}29,700 \pm \\
1100\end{array}$ & & \\
\hline \multicolumn{8}{|l|}{$\begin{array}{c}\text { Rock-art } \\
\text { dates }\end{array}$} \\
\hline $\begin{array}{l}\text { Radiating } \\
\text { lines }\end{array}$ & & charcoal & $0 Z C 608$ & $\begin{array}{l}\text { assumed } \\
-25.0\end{array}$ & $1010 \pm 60$ & $\begin{array}{l}801-888 \\
(74.1 \%) \\
897-927 \\
(25.9 \%)\end{array}$ & $\begin{array}{c}746-963 \\
(100 \%)\end{array}$ \\
\hline $\begin{array}{l}\text { Anthropo- } \\
\text { morph }\end{array}$ & & charcoal & $0 Z D 427$ & $\begin{array}{l}\text { assumed } \\
-25.0\end{array}$ & $1480 \pm 50$ & $\begin{array}{c}1292-1360 \\
(100 \%)\end{array}$ & $\begin{array}{c}1263-1414 \\
(100 \%)\end{array}$ \\
\hline $\begin{array}{c}\text { Anthropo- } \\
\text { morph }\end{array}$ & & charcoal & $0 z C 848$ & $\begin{array}{l}\text { assumed } \\
-25.0\end{array}$ & $1570 \pm 110$ & $\begin{array}{c}1316-1518 \\
(100 \%)\end{array}$ & $\begin{array}{c}1186-1202 \\
(0.8 \%) \\
1244-1247 \\
(0.1 \%) \\
1256-1635 \\
(96.3 \%) \\
1647-1694 \\
(2.8 \%)\end{array}$ \\
\hline $\begin{array}{c}\text { Anthropo- } \\
\text { morph }\end{array}$ & & charcoal & $0 Z D 425$ & $\begin{array}{l}\text { assumed } \\
-25.0\end{array}$ & $1700 \pm 90$ & $\begin{array}{c}1415-1620 \\
(94.8 \%) \\
1673-1687 \\
(5.2 \%)\end{array}$ & $\begin{array}{c}1343-1740 \\
(98.8 \%) \\
1757-1778 \\
(1.2 \%)\end{array}$ \\
\hline
\end{tabular}


to have been caused by higher rainfall levels resulting in the disturbance of sediments and lag deposits. Increased humid conditions appear to have damaged this part of the archaeological assemblage at Hay Cave through migrating driplines and lag or mixed deposits whereby fine particles, but not the coarse sediment fraction, have been removed (see below). Between XU36 and XU46 sediments are clayey but incorporate large amounts of coarser-grained components, including peak quantities of land-snail shell and calcium carbonate concretions (Figure 6). These XUs represent the final period of the Pleistocene to the mid Holocene when rainfall levels are known to have peaked. The large numbers of land-snail shell and peak frequencies of calcium-carbonate concretions in these levels include the early Holocene period of heightened humidity, consistent with both items themselves signalling wetter conditions.

Secondly, the complex of hearths from SU1 (cf. Figure 5) appear to have intruded into and disturbed underlying stratigraphic levels from earlier periods, such as those of SU2a and SU2b. SU1 is composed of numerous in situ hearths and hearth material, as well as representing the period of time when the cave was most intensively used by people and thus suffered the greatest amount of treadage (see below). Intrusive hearths and related activities, therefore, can be expected to have caused some disturbance to earlier sediments, including mixing of small charcoal particles such as those used here in our AMS determinations, particularly at stratigraphic interfaces representing ancient surfaces.

\section{Palaeoenvironments: Land-snail shells}

Information on palaeoenvironmental dynamics for the Chillagoe Formation has been obtained through an examination of the geographical distribution, and ecological and biological characteristics, of the helicinid terrestrial mollusc shell Pleuropoma extincta (Odhner 1917). The use of $P$. extincta remains for palaeoenvironmental reconstruction at Hay Cave is dependent on two main factors: firstly, the capacity of the species to show a measurable response to environmental change; and secondly, the ability to recover sufficient undamaged shell material from the archaeological excavation.

Pleuropoma extincta's current restriction to the vine-thicket communities of the Chillagoe Formation is indicative of an acute sensitivity to regional and local moisture supply. The species occurs abundantly both as living populations on the limestone rock and associated vegetation, and as dead shells in the litter deposits. It has not been recorded from the more expansive eucalypt forest/woodland communities which dominate much of the region. An analysis of 1140 modern P. extincta shells from 23 collection localities within the Chillagoe Formation confirmed a sensitivity in shell growth (measured as size-correlated differences in shell whorl count) to environmental moisture availability. Differences in shell size and pattern between populations of $P$. extincta correlate positively with a declining regional north-south gradient in annual average rainfall and mean number of rain days. Measurements made on shells collected from the northern Mitchell-Palmer limestone belt are consistently more than those gathered from the Chillagoe-Mungana limestone belt further south, where the former recorded higher rainfall statistics than the latter. This apparent variation in the shell size of modern P. extincta is consistent with findings of environmental moisture-related variation in the shell size of terrestrial molluscs from the Kimberley in northwestern Australia (Solem and Christensen 1984) and several other detailed studies (e.g. Tillier 1981; Gould 1984) that suggest moisture is the critical factor in determining size and shape in mollusc species and between populations, more so than temperature, insolation, population density or the availability of calcium. Full details of these modern P. extincta investigations have been presented in Rowe (1998) and Rowe et al. (2001).

A total of 295 sub-fossil specimens of P. extincta were recovered from archaeological excavations at Hay Cave. A high incidence of terrestrial mollusc shell (of all species) by weight 
occurred after ca. 13,600 BP to around or shortly before $3100 \mathrm{BP}$ (XU49-XU38), incorporating a peak (688.0 g) at XU40. Before this time, total shell incidence is comparatively low. Above $\mathrm{XU} 38$, a pronounced decrease to almost negligible occurrence is evident, encompassing the period ca. $3100 \mathrm{BP}$ to present. In the excavated P. extincta shells, mean whorl counts, heights and diameters peak between 13,600 BP and 13,420 BP (XU49-XU45) and all shell parameters have high values between 13,600 BP and $3100 \mathrm{BP}$ (XU49-XU34), declining after ca. 3100 BP before a secondary peak through the period ca. 820-660 BP (XU12-XU6). Low values continue to the present.

Palaeoenvironmentally, both the incidence of terrestrial mollusc shell and the variation in P. extincta shell size with depth indicate dry conditions during the late Pleistocene leading into the terminal Pleistocene/Holocene boundary. This is followed by a period of increased (to peak) precipitation encompassing the early and mid Holocene, until approximately $3100 \mathrm{BP}$, in turn followed by an effective drying. Although dry, the last ca. 3100 years appear to have incorporated a wetter phase around 820-660 BP, suggesting a degree of local precipitation and general climatic variability. These major changes in moisture regimes are thought to have affected the spread, floristic structure and complexity of the vine-thicket communities throughout the Chillagoe Formation. Vine-thicket communities would have had a maximum distribution beyond the current confines of the limestone outcrops, displacing areas of sclerophyll vegetation between ca. 13,600 BP and 3100 BP. A late-Holocene drier climate allowed for a reinvasion of the sclerophyll vegetation, reducing the P. extincta habitat. The Chillagoe Formation vine thickets are therefore remnants of a more extensive late-Pleistocene to mid-Holocene flora, now represented as permanent refugia. The local Chillagoe Formation palaeoenvironmental results are, overall, consistent with higher rainfall regimes and associated maximum extent of humid rainforests during the early and mid Holocene on the Queensland east coast, as informed by palynological data (Kershaw et al. 1993; Kershaw 1994). However, the P. extincta shell data suggestion of an earlier increase in moisture availability, close to 13,600 BP west of the Great Dividing Range, warrants further investigation.

\section{Palaeotemperatures: Alectura lathami egg shells}

The chronology of Hay Cave has also been assisted by examination of the remains of brush-turkey egg shell from its deposits. The extent of isoleucine epimerisation in Australian brush-turkey (Alectura lathami) egg shell from Hay Cave was reported by Clarke 2005 and Clarke et al. 2007. Isoleucine epimerisation (a diagenetic reaction analogous to amino acid racemisation) is the interconversion of the epimers L-isoleucine (Ile) and D-alloisoleucine (aIle), and is expressed as the ratio of these two molecules (aIle/Ile). In modern Alectura egg shell the alle/Ile value is approximately 0.02 and increases towards a value of 1.30 at dynamic equilibrium.

A total of 99 Alectura egg-shell fragments excavated from Square M30 of Hay Cave were subjected to isoleucine epimerisation analyses. These egg shells primarily come from the upper $75 \mathrm{~cm}$ of the sequence; below these depths, egg shell was rare or absent. The values fall into three main clusters: $0.02<$ aIle/Ile $<0.05,0.05<$ alle/Ile $<0.08$, and $0.13<$ alle/Ile $<0.16$. These clusters are identified as A, B and C, respectively. Not incorporated in these three clusters are the aIle/Ile values of three egg shells, one of which falls between clusters B and C. The other two have aIle/Ile values greater than those observed in cluster $\mathrm{C}$. The two egg shells with aIle/Ile values exceeding these ranges are not considered further as they are likely to reflect the influence of campfire heating on the rate of isoleucine epimerisation (Clarke et al. 2007).

The correlation between Alectura egg shell alle/Ile values and calibrated radiocarbon ages (median of the $1 \sigma$ range) obtained on the same samples can be approximated using a simple linear model that estimates that the extent of isoleucine epimerisation increases by 0.020 alle/ 
Ile units every 1000 years. The root mean square error of this regression predicts that the model can be used to interpret aIle/Ile in terms of sample age with an uncertainty of approximately \pm 470 years (when the average analytical uncertainty of \pm 0.005 alle/Ile units is included).

Three groups corresponding to clusters A, B and C are identified in the depth-age profile of the isoleucine epimerisation ages in the Hay Cave sequence. The implication is that three major chrono-stratigraphic phases can be identified from these data. The egg shells of cluster A were recovered from depths close to the surface down to approximately $40 \mathrm{~cm}$ and have age estimates of ca. 0-1500 years. The cluster B egg shells occupied depths between $40 \mathrm{~cm}$ and $65 \mathrm{~cm}$ and have ages of ca. 2000-3000 years. The egg shells of cluster $\mathrm{C}$ came from sediments at about $65-70 \mathrm{~cm}$ depth and have ages of approximately ca. 6000-7000 years. The apparently young egg shells from clusters A and B found at depths below the above-mentioned respective depths are explained, along with other radiocarbon dates, as most likely due to one of two possibilities: either post-depositional contamination through treadage and related activities, or the intrusion of hearths in the suite of Excavation Units spanning XU35-44, at the stratigraphically indistinct Pleistocene-Holocene interface (see above).

\section{Archaeological materials: Temporal trends}

To address questions of temporal trends in cultural activity and intensity of site occupation, studies have been carried out on the rock art and the main archaeological materials from Square M30: stone artefacts, animal bone, land-snail shell and brush-turkey egg shell (see Table 4 for a list of excavated materials by XU). The results of these studies are presented below.

\section{Stone artefacts}

The analysis of the stone artefacts focuses on the question of 'intensity of site use' through time. Holden (1999:31-46) followed the methods of Hiscock (1988:163-228) at Colless Creek, Mitchell (1988) at Seal Point, and Lamb (1994) at Fern Cave to demonstrate that discard rates of stone artefacts alone are insufficient measures of 'intensities of site use', as other factors may also critically affect the number of artefacts produced and discarded at a site. These factors include the manufacturing process (e.g. the use of blade versus non-blade technologies; bipolar versus freehand flaking techniques; heat treatment), lithic resource manipulation (e.g. decortication at the quarry versus all stages of core reduction on-site) and taphonomic processes (e.g. post-depositional heat shatter from adjacent hearths; removal of small artefacts by water action). A set of appropriate multiple attributes was thus used to investigate these processes at Hay Cave (see Holden 1999 for a detailed analysis of the Hay Cave stone artefacts). Here we present a summary of these results.

Quantities of stone artefacts from SU2 and SU3 at Hay Cave were too low to conclusively assess changes in human activity during those periods. Suggestive trends, however, were apparent. In general, deposition rates of the weight of stone material through the deposit strongly correlate with those of burnt earth, mussel shell and egg shell (Figure 6). The few stone artefacts in the lower levels suggest overall low levels of site use between ca. 30,000 BP and $13,600 \mathrm{BP}$, followed by much reduced numbers or a possible hiatus in occupation during the early Holocene when the cave might have been too humid for regular occupation, with peak levels of human activity taking place after ca. $3000 \mathrm{BP}$ and continuing until the near-present. Holden argued that after ca. 3000 BP, increases in the frequency, length of duration of stay or number of people using the site (all of which potentially contribute to increased intensities of site use) boosted the demand on stone, leading to practices aimed at conserving the resource. For example, during the late Holocene, an emphasis was placed on later stages of reduction, with high levels of controlled flaking, along with increased lithic discard rates. Fluctuations in lithic deposition rates appear to be unrelated to differential activity locations, raw-material selection or taphonomic processes, and are thus largely explained by changing intensities of site use by people (Figure 6; see Holden 1999 for specific details). 


\begin{tabular}{|c|c|c|c|c|c|c|c|c|c|c|c|c|c|c|c|c|c|c|c|c|c|c|c|c|}
\hline 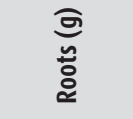 & $\stackrel{0}{\circ}$ & : & $\begin{array}{l}\stackrel{\circ}{\Gamma} \\
\dot{\Gamma}\end{array}$ & $\widehat{\mathrm{b}}$ & 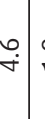 & 'L & în & & $\underset{\sim}{\stackrel{j}{~}}$ & $\stackrel{0}{\wedge}$ & $\begin{array}{l}0 \\
\text { r. }\end{array}$ & $\overline{\mathrm{i}}$ & 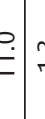 & & $\stackrel{r}{\stackrel{n}{r}}$ & Fं & $\mid \begin{array}{l}n \\
0\end{array}$ & $\stackrel{n}{\sim} \underset{\sim}{\sim}$ & $\stackrel{i}{\sim}$ & $\check{f}$ & \begin{tabular}{l|l}
0 \\
\\
& in \\
$m$
\end{tabular} & $\begin{array}{l}0 \\
\rho_{m}^{0}\end{array}$ & 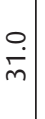 & $\stackrel{\sim}{\stackrel{f}{*}}$ \\
\hline 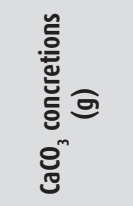 & & & & & & & & & & & & & & $\pi$ & & - & & & $\approx$ & & $\wedge m$ & & & \\
\hline 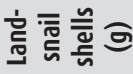 & $-\dot{0}$ & $\stackrel{\text { n }}{\sim}$ & $\bar{m}$ & $\stackrel{0}{-}$ & $\stackrel{m}{\sim}$ & $\begin{array}{c}\infty \\
0 \\
0\end{array}$ & $=$ & & นก & $\grave{o}$ & \begin{tabular}{l|l|l}
$\infty$ & \\
$\circ$ &
\end{tabular} & $\begin{array}{c}m \\
0\end{array}$ & 5 & $?$ & $\stackrel{0}{i} \stackrel{\rightarrow}{r}$ & - & 足 & 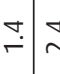 & $\bar{i}$ & $\stackrel{\leftrightarrow}{?}$ & $\stackrel{0}{\sim}: 2$ & $\stackrel{m}{\sim}$ & $\stackrel{\leftrightarrow}{\dot{*}}$ & $\stackrel{a}{m}$ \\
\hline 志 气 & & & & & & & & & & & & 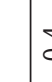 & : & & & & & & & & & & & \\
\hline 壳芯正 & & & & & & & & & & & & r & & & & & & & & & & & & \\
\hline 芯言五 & & & & & & & & & & & & & & & & & & & & & & & & \\
\hline 䓌 & & & & & & & & & & & & & & & & & & & & & $\frac{7}{7}$ & & & \\
\hline 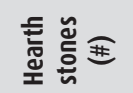 & & & & & & & & & & & & & & & & & & & & & $\tau$ & & & \\
\hline 梽 & $\stackrel{\infty}{\sim}$ & $\mid \begin{array}{c}n \\
\stackrel{n}{\sim}\end{array}$ & 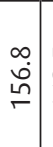 & 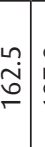 & 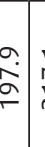 & E. & \begin{tabular}{c}
$m$ \\
\hdashline
\end{tabular} & $\begin{array}{l}y \\
n\end{array}$ & नें & $\begin{array}{l}0 \\
\dot{0} \\
0\end{array}$ & 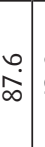 & $\begin{array}{l}\dot{q} \\
\dot{q}\end{array}$ & $=$ & $\begin{array}{l}2 \\
0 \\
0\end{array}$ & 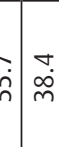 & $\left|\begin{array}{l}\vec{d} \\
\dot{m}\end{array}\right|$ & $\mid \begin{array}{l}\infty \\
\dot{\sim} \\
\sim\end{array}$ & 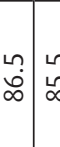 & $\frac{1}{6}$ & $\mid \begin{array}{l}a \\
\dot{m} \\
m\end{array}$ & 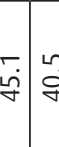 & $\dot{\dot{m}}$ & $\begin{array}{l}\dot{q} \\
\dot{g}\end{array}$ & 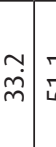 \\
\hline 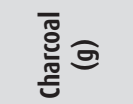 & $\check{\dot{v}}$ & in & $\begin{array}{l}\stackrel{\infty}{\leftarrow} \\
\stackrel{\sigma}{\sigma}\end{array}$ & $\stackrel{\circ}{\circ}$ & นุ? & $\sigma$ & 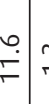 & $?$ & $\stackrel{+}{\infty}$ & 吕 & ¿े. & 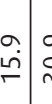 & $\dot{m}$ & \begin{tabular}{c}
$n$ \\
\hdashline \\
$z$
\end{tabular} & 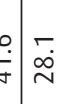 & $\begin{array}{l}0 \\
\dot{0} \\
\end{array}$ & $\begin{array}{l}\stackrel{n}{n} \\
\stackrel{n}{n}\end{array}$ & 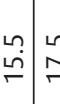 & $? \begin{array}{l}\sim \\
\stackrel{n}{\sim} \\
\sim\end{array}$ & 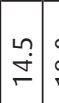 & \begin{tabular}{l|l}
0 \\
$\infty$ \\
\hdashline \\
$c$
\end{tabular} & $\stackrel{\sim}{\sim}$ & $\begin{array}{l}\stackrel{\circ}{\dot{r}} \\
\end{array}$ & \begin{tabular}{l|l}
1 & \multicolumn{1}{c}{} \\
$\infty$ & 7 \\
\end{tabular} \\
\hline $\begin{array}{l}\overline{\bar{\Xi}} \\
\text { 畜 } \\
\text { g }\end{array}$ & $\dot{\bar{v}}$ & & בָ & $\begin{array}{l}\tilde{m} \\
\tilde{m}\end{array}$ & $\stackrel{m}{\sim}$ & $\stackrel{m}{m}$ & $\stackrel{\leftrightarrow}{\stackrel{n}{\longrightarrow}}$ & & $\stackrel{n ?}{\longrightarrow}$ & $\stackrel{m}{\sim}$ & $\stackrel{\infty}{\stackrel{\infty}{\sim}}$ & $\stackrel{\circ}{\circ}:$ & $=2$ & 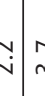 & $\dot{n} \stackrel{\dot{m}}{\dot{m}}$ & $\stackrel{n}{\mathrm{i}}$ & $\mid \begin{array}{l}\infty \\
0 \\
0\end{array}$ & 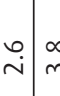 & $\stackrel{p}{i}: \tilde{c}$ & 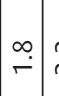 & $\stackrel{\sim}{\sim}$ & $\stackrel{m}{\sim}$ & $\stackrel{\sim}{N}$ & $\stackrel{\infty}{\longrightarrow}$ \\
\hline 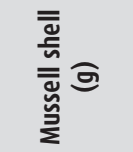 & & $\begin{array}{l}\tilde{o} \\
0\end{array}$ & $\stackrel{\sim}{\longrightarrow}$ & : & $\stackrel{9}{-}$ & ה & $\stackrel{m}{\sim}$ & & $\stackrel{a}{0}$ & $\dot{\vec{\sigma}}$ & $\stackrel{m}{m}$ & $\stackrel{n}{\longrightarrow}$ & $\begin{array}{l}v^{2} \\
\end{array}$ & $\bar{\circ}$ & $\dot{\dot{m}}$ & $\stackrel{\infty}{\sim}$ & $\mid \begin{array}{l}0 \\
\stackrel{0}{r}\end{array}$ & $\stackrel{0}{\sim}$ & $\begin{array}{l}\dot{f} \\
\dot{f}\end{array}$ & $\stackrel{\circ}{\circ}$ & $\begin{array}{c}\dot{\vec{v}} \\
v\end{array}$ & $\begin{array}{l}m \\
0\end{array}$ & б. & $\overline{0}$ \\
\hline 芯 & & $\stackrel{\circ}{+}$ & $\stackrel{\overbrace{}}{\check{\digamma}}$ & 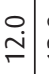 & 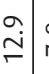 & $\stackrel{\infty}{\sim}$ & $\stackrel{\leftrightarrow}{\rightarrow}$ & : & $\bar{\infty}_{\infty}$ & $\stackrel{\vec{\sim}}{ }$ & i. & $\overline{\mathrm{i}}$ & مُ & จ. & $\dot{0}$ & 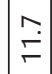 & i̊ & 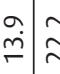 & 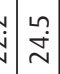 & $\begin{array}{l}0 \\
\infty \\
\infty \\
\infty\end{array}$ & 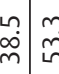 & $\stackrel{\substack{n \\
\sim}}{\sim}$ & 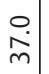 & 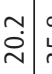 \\
\hline 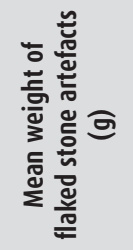 & 亏. & $\mid$ & $\begin{array}{l}\tilde{O} \\
0\end{array}$ & $\begin{array}{l}\hat{0} \\
0 \\
0\end{array}$ & $\begin{array}{c}\text { Na } \\
\vdots\end{array}$ & 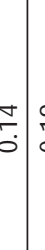 & 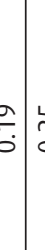 & $\begin{array}{c}n \\
S \\
\end{array}$ & 官 & ơ & $\begin{array}{l}0 \\
\vdots \\
0\end{array}$ & 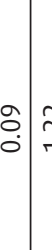 & 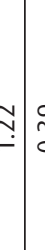 & 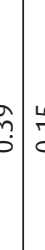 & $\begin{array}{l}n \\
\dot{0} \\
\dot{n}\end{array}$ & $\left|\begin{array}{l}\infty \\
0 \\
0\end{array}\right|$ & $\left|\begin{array}{l}- \\
\infty \\
0\end{array}\right|$ & \begin{tabular}{l|l}
0 \\
\hdashline & $\bar{c}$
\end{tabular} & $\begin{array}{l}0 \\
\vdots \\
0 \\
0 \\
0\end{array}$ & 番 & 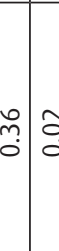 & 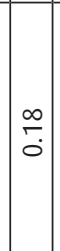 & हn. & 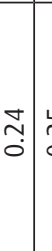 \\
\hline 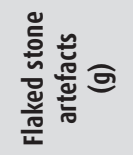 & $\begin{array}{l}\tilde{1} \\
\tilde{0} \\
\end{array}$ & $\mid \begin{array}{l}\stackrel{u}{o} \\
\stackrel{r}{r}\end{array}$ & $\begin{array}{l}n \\
0 \\
0\end{array}$ & $\begin{array}{l}0 \\
0 \\
0\end{array}$ & $\begin{array}{l}0 \\
\dot{0} \\
0\end{array}$ & ְै & $\begin{array}{c}\infty \\
m\end{array}$ & $\begin{array}{l}0 \\
\vdots \\
\end{array}$ & $\mid \begin{array}{c}\infty \\
\infty \\
m\end{array}$ & $\mid$ & 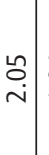 & 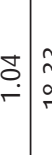 & $\begin{array}{l}n \\
0 \\
0\end{array}$ & $\begin{array}{l}b_{0} \\
0\end{array}$ & 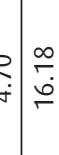 & 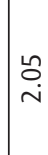 & $\left|\begin{array}{c}\stackrel{\sim}{\sim} \\
\tilde{m}\end{array}\right|$ & 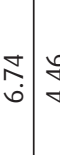 & 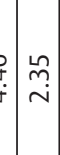 & $\stackrel{m}{m}$ & 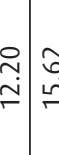 & 足 & $\begin{array}{l}0 \\
\stackrel{0}{0} \\
\dot{m}\end{array}$ & \\
\hline 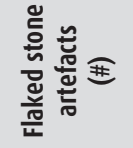 & - & $\nabla$ & $\sim$ & $\stackrel{m}{=}$ & $\stackrel{2}{2}$ & $=$ & $\infty$ & & $\stackrel{\circ}{\circ}$ & $\nexists$ & $\bar{\sim}$ & $\simeq$ & 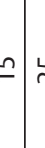 & $\hat{N}=$ & $\bar{n} \bar{m}$ & $\stackrel{2}{2}$ & $\nabla$ & $\tilde{\gamma} \tilde{m}$ & $\stackrel{\infty}{\sim}$ & $m$ & $\dot{m} \stackrel{m}{\sim}$ & $\stackrel{\infty}{m}$ & in & $\stackrel{\infty}{+} \mid$ \\
\hline $\bar{z}$ & - & $\sim$ & $m$ & $\checkmark$ & in & 。 & N & 0 & 웅 & $\mp$ & $\simeq$ & 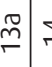 & \pm & $f=$ & $=\neq$ & $\stackrel{\infty}{\perp}$ & $\stackrel{2}{\circ}$ & ৯ & $\approx \pi$ & $\approx$ & $\Delta \stackrel{\sim}{\sim}$ & $\stackrel{\infty}{\sim}$ & 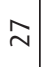 & 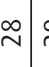 \\
\hline
\end{tabular}




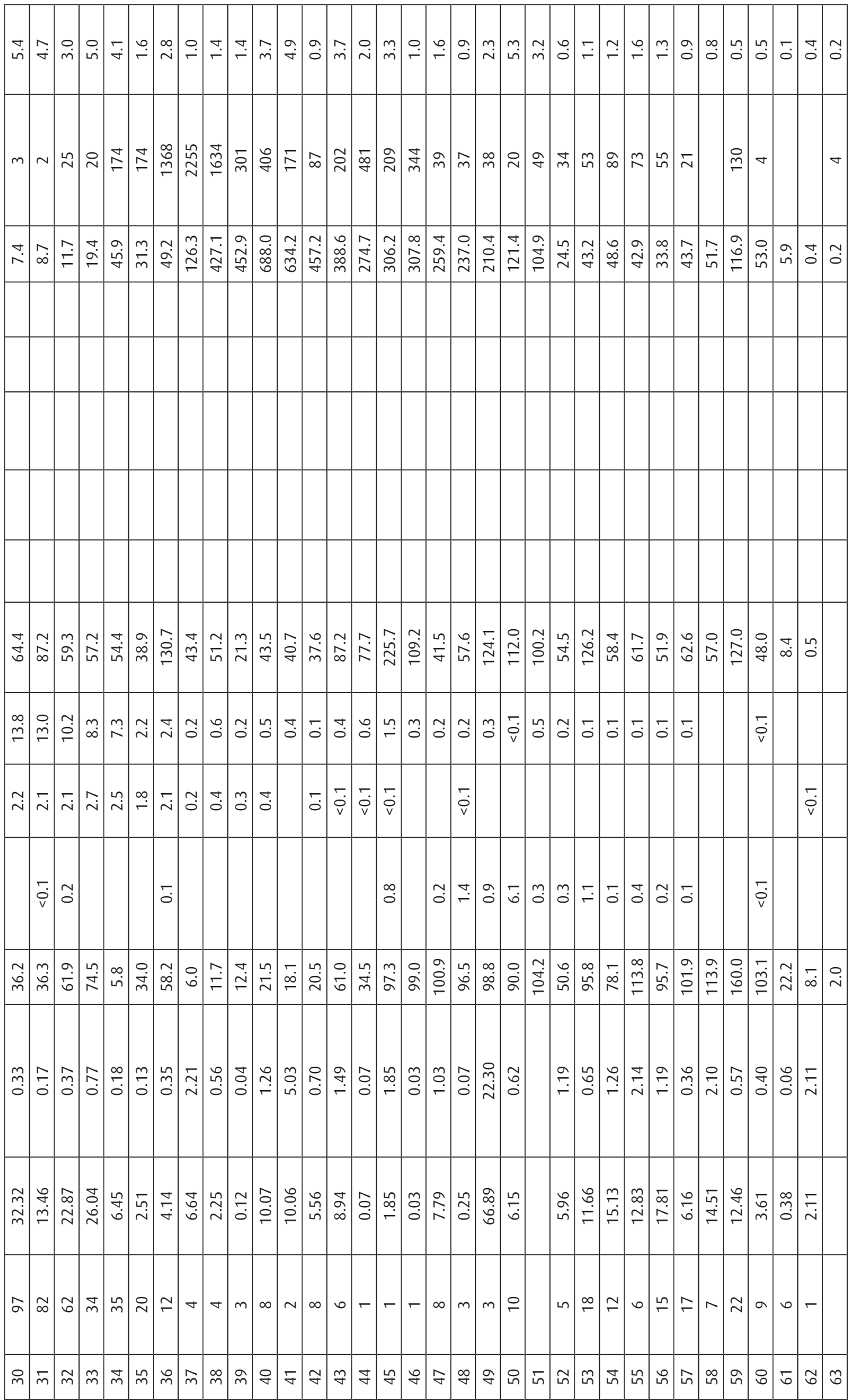


Table 5. Teeth and jaw fragment NISP, Hay Cave Square M30 (after Roche 1999:82, table VI).

Taxon

Mocropus

Macropus

agilis

Macropus

giganteus

Macropus

parryi

Macropus

robustus

Petrogale

sp.

Macropo-

didae (sp.

indetermi-

nate)

Trichosurus

vulpecula

Petaurus

norfolcen-

sis

Isoodon

obesulus

Isoodon

macrourus

Perameles

nasuto

Bettongio

tropica

Dasyurus

hallacatus

Dasyuridae

(sp. indeter-

minate)

Phoscogale

topoatafo

Phoscogale

(sp. indeter-

minate)

Sminthop-

sis murino

Conilurus

penicillatus

Mesembri-

yos gouldii

Uromys

coudimac-

ulatus

Rattus tun-

neyi

Rattus (sp.

indetermi-

nate)

Excavation Unit

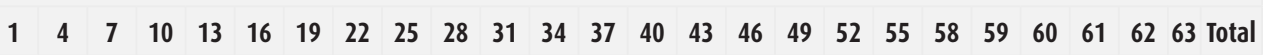

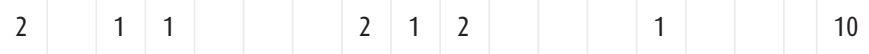

\begin{tabular}{l|l|l}
2 & 1 & 1
\end{tabular}

2112

10

1

1

\begin{tabular}{l|l|l|l}
1 & 1 & 2 & 5
\end{tabular}

10

11

1

\begin{tabular}{llllll|l|l|l|l|l|l|l|l|}
7 & 5 & 7 & 5 & 2 & 4 & 5 & 3 & 3 & 12 & 18 & 16 & 12 & 3
\end{tabular}

103

1

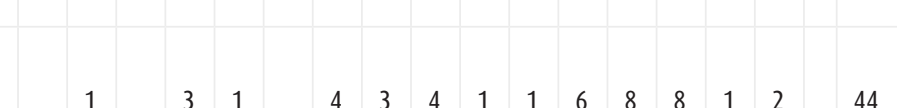

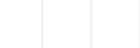

1

1

$\begin{array}{ll}3 & 1\end{array}$

$\begin{array}{llllllllllll}4 & 3 & 4 & 1 & 1 & 6 & 8 & 8 & 1 & 2\end{array}$

44

1

\begin{tabular}{l|l|l}
1 & 1 & 2
\end{tabular}

5

2

1

2

2

$1 \quad 1$

1

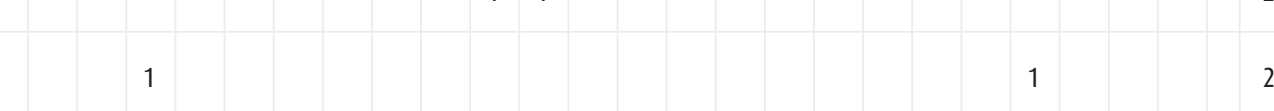

11

2

$\begin{array}{lll}1 & 1 & 2\end{array}$

e

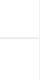

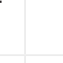

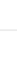

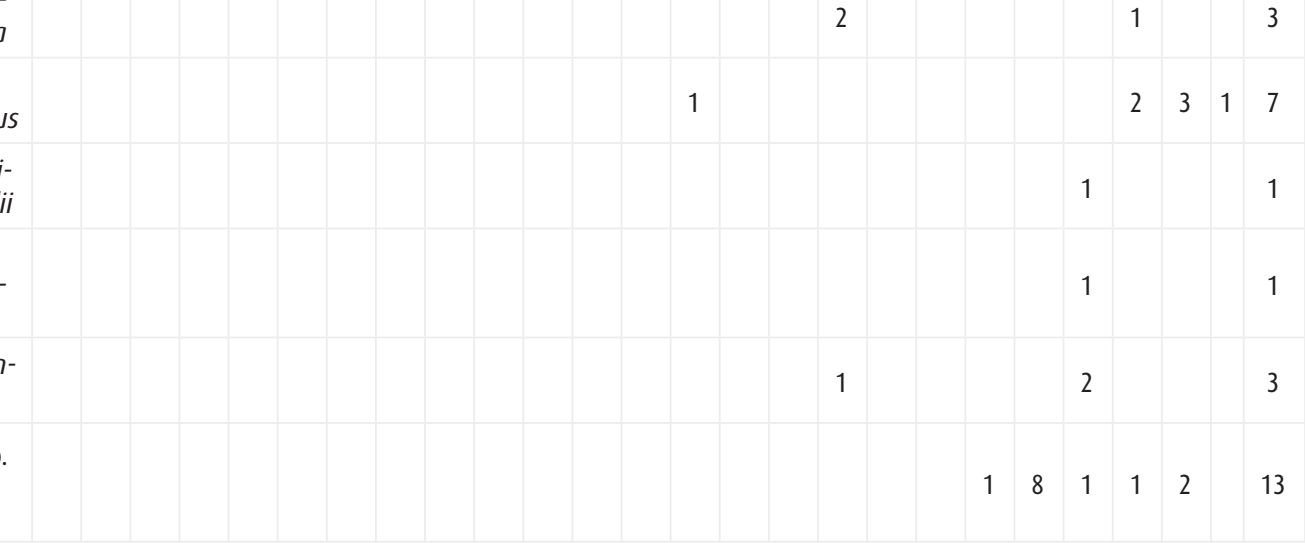


Table 5. Continued

\begin{tabular}{|c|c|c|c|c|c|c|c|c|c|c|c|c|c|c|c|c|c|c|c|c|c|c|c|c|c|c|}
\hline \multirow{2}{*}{ Taxon } & \multicolumn{26}{|c|}{ Excavation Unit } \\
\hline & 1 & 4 & 7 & 10 & 13 & 16 & 19 & 22 & 25 & 28 & 31 & 34 & 37 & 40 & 43 & 46 & 49 & 52 & 55 & 58 & 59 & 60 & 61 & 62 & & Total \\
\hline $\begin{array}{l}\text { Melomys } \\
\text { burtoni }\end{array}$ & & & & & & & & & & & & & & & & & & & & & 1 & 1 & & & 1 & 3 \\
\hline $\begin{array}{l}\text { Zyzomys } \\
\text { argurus }\end{array}$ & & & & & & & & & & & & & & & & & & & & & & & 1 & & & 1 \\
\hline $\begin{array}{l}\text { Pseudomys } \\
\text { gracilicau- } \\
\text { datus }\end{array}$ & & & & & & & & & & & & & & 2 & 2 & 1 & 4 & & & 2 & 10 & 9 & 3 & 1 & 1 & 35 \\
\hline $\begin{array}{l}\text { Pseudomys } \\
\text { patrius }\end{array}$ & & & & & & & & & & & & & & & & & & & & & & 1 & & & & 1 \\
\hline $\begin{array}{l}\text { Pseudomys } \\
\text { sp. } 1\end{array}$ & & & & & & & & & & & & & & 1 & & 1 & 1 & & & & 1 & & & & 1 & 5 \\
\hline $\begin{array}{l}\text { Muridae (sp. } \\
\text { indetermi- } \\
\text { nate) }\end{array}$ & & & & & 1 & & & & & & & 3 & & 1 & 2 & 3 & 4 & 3 & 4 & 7 & 39 & 72 & 24 & 13 & 1 & 177 \\
\hline $\begin{array}{l}\text { Tiliqua } \\
\text { scincoides }\end{array}$ & & & & & & & & & & & & & & & & 1 & & & & & & & & & & 1 \\
\hline Total & & 4 & 2 & 3 & 3 & 0 & 0 & 0 & 10 & 9 & 10 & 14 & 1 & 7 & 12 & 17 & 23 & 10 & 19 & 39 & 88 & 110 & 37 & 22 & 6 & 443 \\
\hline
\end{tabular}

\section{Vertebrate faunal remains}

Roche (1999) extended the above study by examining the animal bone from Square M30. Because of the large quantities of bone present, the bones were identified from every third XU down to XU57, below which every XU was analysed for taxonomic identifications. For analytical purposes, Roche divided the excavated sequence into arbitrary units, each representing a period of approximately 3000 years (Analytical Units 1-5, excluding Analytical Unit 2a, which is added here for the purposes of this paper). The Analytical Units followed the timeframes below, and were based on extrapolation from the depth-age curve (Hughes and Djohadze 1980):

Analytical Unit 1: [XU1-34, representing 150 BP to 3000 BP]

Analytical Unit 2a: [XU35 to 40, representing $3000 \mathrm{BP}$ to $12,000 \mathrm{BP}$ ]

Analytical Unit 2b: [XU41-52, representing 12,000 BP to 15,000 BP]

Analytical Unit 3: [XU53-56, representing 16,000 BP to 19,500 BP]

Analytical Unit 4: [XU57-59, representing 23,500 BP to 27,000 BP]

Analytical Unit 5: [XU60-63, representing 29,500 BP to 32,000 BP]

These Analytical Units are distinct from the SUs and XUs that structured the excavation itself, and were employed to facilitate examination of temporal trends through the use of chronological units of roughly equal, and therefore more comparable, duration. The identifiable bone was analysed by Minimum Number of Individuals (MNI), and the unidentified, fragmented bone by the Number of Identified Specimens (NISP) (cf. Grayson 1984:28, 30; Lyman 1994:98,100). Bone deposition rates (Figure 6) conform to the general trends observable in other cultural indices, except that high levels also occur between ca. 32,000 BP and 18,000 $\mathrm{BP}$ when other indices are low; and levels increase markedly between ca. 15,000 BP and 12,500 BP. Bone, therefore, appears prominent in the lower and middle units (Anaytical Units 5, 4, 2). 

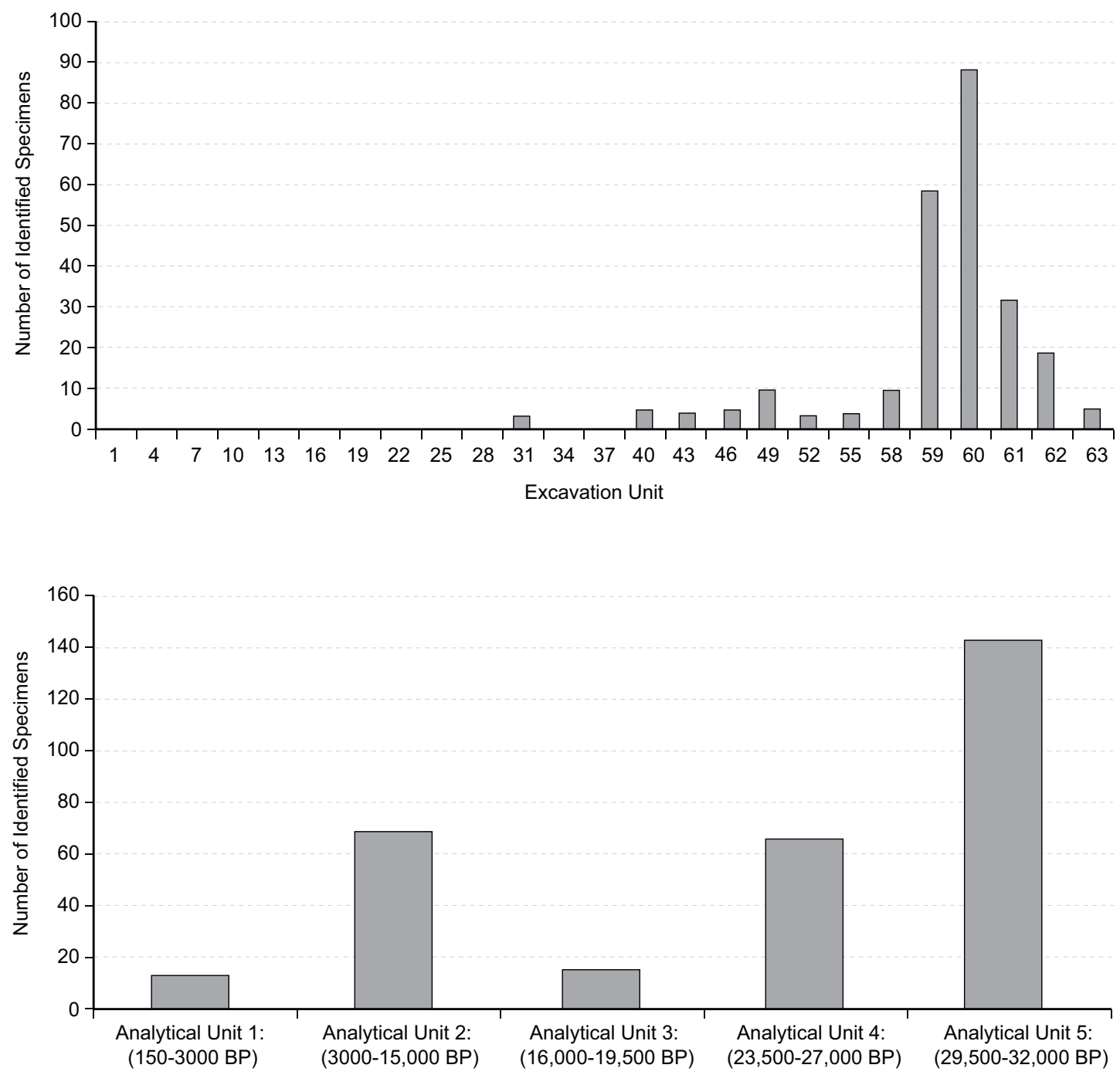

Figure 7. Distribution of murid bones by XU (top) and by Analytical Unit (bottom), Square M30.

As soil $\mathrm{pH}$ remained constant throughout the deposit, general variations in quantities of bone over time are not related to changes in the acidity of the matrix. There is a generally high rate of post-cranial fragmentation throughout (more than $90 \%$ of the fragments are smaller than $15 \mathrm{~mm}$ ); frequencies of skeletal elements revealed little variation between $\mathrm{XU}$, with limb bones being the most common post-cranial bones. All calculations in this analysis were adjusted for temporal variation between XUs. Calcined and carbonised bones are present in almost all XUs and highest between XU34-28 and XU52-46. That is, burned bone is most evident between ca. 3000-2500 BP and ca. 15,000-13,500 BP, which we argue represents those levels when the site was most heavily used by people. The presence of burnt bone in Hay Cave cannot be attributed to natural (bush) fires due to its protected location inside a cave which is itself surrounded by fire-protected limestone pediments; furthermore, the presence of calcined bone is generally understood to be closely related to human activity (e.g. Shipman et al. 1984:323; David 1990:75).

Taxonomic identifications were undertaken on teeth and jaws, indicating the presence of 24 distinct species plus five indeterminate family- or genus-level taxa which could not be attributed to species (Table 5). Macropod bones are present in almost all XUs, with NISP peak deposition periods in XU34-25 (the lower part of Analytical Unit 1) and XU52-43 (Analytical Unit $2 \mathrm{~b}$ ) - that is, between ca. $3000 \mathrm{BP}$ and $2500 \mathrm{BP}$ and between ca. 15,000 BP and 13,500 BP. Macropod MNI are highest in Analytical Unit 1 (ca. 3000 BP and 150 BP)(Table 6). 
Table 6. Description of Analytical Units (see Roche 1999:101-11 for further details).

\begin{tabular}{|c|c|c|}
\hline $\begin{array}{c}\text { Analytical } \\
\text { Unit }\end{array}$ & Years BP & Description \\
\hline 1 & $150-3000$ & $\begin{array}{l}\text { This unit contains the fastest sedimentation rates, peak proportions of macropods, and the } \\
\text { second-highest value of calcined bone. There is also evidence for the rationing and conservation } \\
\text { of stone (Holden 1999:96), indicating that demands on lithic raw materials were high. All of the } \\
\text { dated rock art belongs to this time. The complete absence of grassland faunal taxa (with murid } \\
\text { NISP at their lowest) cannot be related to differential environmental or climatic conditions. } \\
\text { Rather, people, with their high incidence of hearths, are inversely correlated with the frequency } \\
\text { of murids at this time (and, by implication, probably also the use of the cave by predatory birds). } \\
\text { Forest faunal taxa also show a marginal decrease from the prior wetter period (of the early to } \\
\text { mid Holocene represented by Analytical Unit 2a). Lower precipitation during Analytical Unit } 1 \text { is } \\
\text { also reflected in low deposition rates of land-snail shell and calcium-carbonate concretions (cf. } \\
\text { Rowe 1998:78-79). }\end{array}$ \\
\hline $2 a$ & $3000-12,000$ & $\begin{array}{l}\text { Between ca. } 3000 \mathrm{BP} \text { and 13,500 BP, land-snail shell and calcium-carbonate deposits increased } \\
\text { noticeably, indicating peak levels of precipitation (Rowe 1998:78-79). The period between } \\
3000 \mathrm{BP} \text { and 12,000 BP is not clearly differentiated at Hay Cave, partly due to the presence of } \\
\text { mixed sediments during this period, the coarser nature of those sediments (indicating that finer } \\
\text { sediments may have been washed away through percolating water action), and the cementing } \\
\text { of sediments in calcium-carbonate concretions. }\end{array}$ \\
\hline $2 b$ & $\begin{array}{c}12,000- \\
15,000\end{array}$ & $\begin{array}{l}\text { Human use of the site is less than during the late Holocene, but higher than preceding Analytical } \\
\text { Units, with high weights of calcined bone and other indices. Murids and macropods are also } \\
\text { abundant, with peak incidence of open forest/woodland taxa. Grassland taxa, however, are little } \\
\text { different in proportion to those of Analytical Units } 4 \text { and 5, indicating that grasslands were not } \\
\text { expansive at this time. During this time, the increased use of the site by people and other fauna, } \\
\text { including murid predators, is related to higher levels of precipitation than previously. }\end{array}$ \\
\hline 3 & $\begin{array}{c}16,000- \\
19,500\end{array}$ & $\begin{array}{l}\text { Human use was marginally more than during the preceding Analytical Unit 4. Here, there is also } \\
\text { a low level of murids, and the second-lowest weight of calcined bone, murid and macropod } \\
\text { NISP. Climatic conditions were dry, as indicated by low levels of land-snail shell and calcium- } \\
\text { carbonate concretions. Low levels also of open forest/woodland animals are consistent with drier } \\
\text { environmental conditions and a reduction in forests. }\end{array}$ \\
\hline 4 & $\begin{array}{c}23,500- \\
27,000\end{array}$ & $\begin{array}{l}\text { A relatively low level of human use is shown by average levels of calcined bone and macropods, } \\
\text { and low levels of flaked stone and burnt earth. There is a high proportion of murids, indicating } \\
\text { that animals and probably predatory birds were frequent users of the cave. }\end{array}$ \\
\hline 5 & $\begin{array}{c}29,500- \\
32,000\end{array}$ & $\begin{array}{l}\text { A low level of human use is indicated by the low amount of calcined bone, the slow rate of } \\
\text { sedimentation, and the lowest values of macropods contrasting with the highest proportions of } \\
\text { murids. }\end{array}$ \\
\hline
\end{tabular}

Greater amounts of macropod than murid bone at a site are usually suggestive of people rather than other predators, even though the diets of people and animal predators may overlap to some extent (Balme et al. 1978:52; Bowdler 1984:63; David 1984b:40). Macropods form a key element of human diets, while murids are more prominent in the diets of other predators, such as birds using caves as roosts. More intensive human use of a cave or rockshelter, therefore, often results in a decline in murid bones due to the presence of hearths and other disturbances to the lair or roost of non-human predators (David 1984a:49). As rates of bone fragmentation remained constant throughout the Hay Cave sequence, differential bone preservation does not appear to account for the changes in the absolute or relative representation of macropods and murids. Frequencies of murid bones can thus be contrasted with frequencies of culturally deposited bones (in particular, macropod) within the deposit. Accordingly, and in contrast with the pattern of macropod bone at Hay Cave, murid NISP are almost totally absent in Analytical Unit 1 when human activity is most prominent (murid bones are absent in XU31-1, except for XU13). They are present in all other Analytical Units, with a peak presence in Analytical Units 4 and 5 (Figure 7). Comparison between Analytical Units 1 and 5, representing the two extremes of highest and lowest human occupation respectively, indicates a marked negative correlation between murid and macropod bone concentrations; when murid concentrations are high, macropod are low, and vice versa. In line with previous studies, such as at Walkunder 


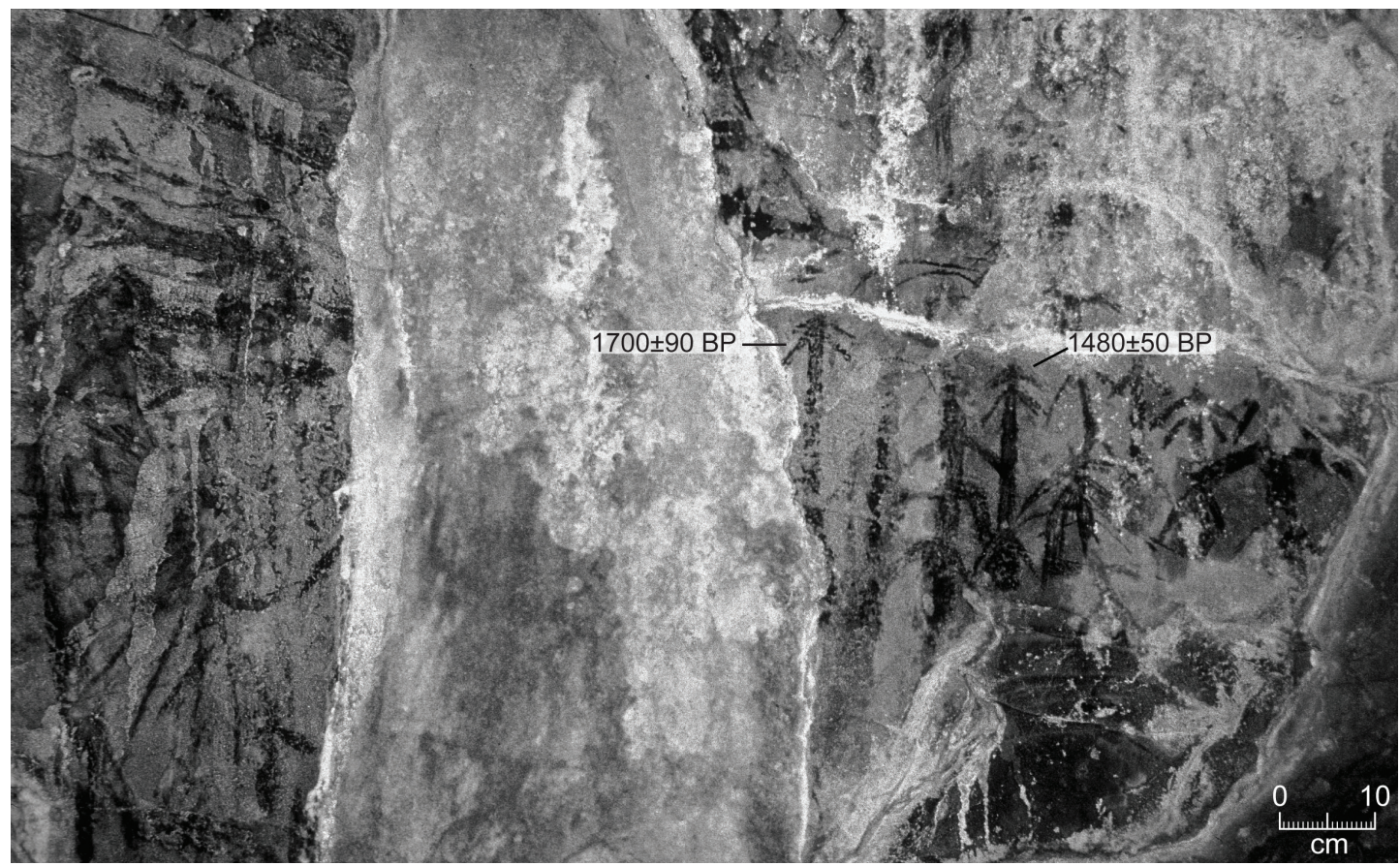

Figure 8. Panel of pigment anthropomorphs, including the two radiocarbon-dated pictures, Hay Cave.

Arch Cave also in the Chillagoe Formation, the implication is that the human use of Hay Cave is significantly greatest during the last ca. 3000 years in Analytical Unit 1 (Roche 1999:80-92).

The frequency of open forest/woodland taxa, as measured by NISP/1000 years, indicates their presence throughout the deposit, with very low frequencies in Analytical Unit 3 (the Last Glacial Maximum) and peak frequencies in Analytical Unit 2 (terminal Pleistocene). This may be an indication of a climatic gradient from maximum aridity to increasing humidity, and therefore a decline in open forest/woodland during the drier Last Glacial Maximum followed by an increase during the more humid terminal Pleistocene into the early Holocene. However, the complete absence of grassland taxa (for example, murids) in Analytical Units 1 and 3 may be related to the increased presence of humans during the late Holocene and possibly the Last Glacial Maximum also. As Analytical Unit 3 represents the glacial maximum - a time of peak aridity when grasslands were more dominant - the results in this case are somewhat ambiguous and may be interpreted either as evidence of changed environmental conditions and/or as a period of increased human presence (Roche 1999:92-100).

If we summarise the data regarding people's activities at Hay Cave, comparing vertebrate faunal evidence with the deposition rates of other cultural materials and with the speed of sediment accumulation through time, peak rates of use by people consistently occur during the late Holocene (especially the past ca. 3000 years in Analytical Unit 1), followed by Analytical Unit 2b (the terminal Pleistocene, ca. 15,000 BP to 12,000 BP), with Analytical Units 3, 4 and 5 showing sequentially decreasing levels.

\section{The rock art}

Hay Cave contains 92 rock pictures, all but four of which are either drawn (mainly in black charcoal) or painted. The drawn and painted art is from here on referred to as 'pigment art'. The other four rock pictures are moderately patinated engravings pecked into the rock wall. Appendix 1 lists each of these rock pictures.

Four radiocarbon determinations were obtained from small scrapings of charcoal pigment art. Two of these are from generalised anthropomorphs located on a small panel near the cave entrance, but well inside the dripline (Figure 8). This decorated panel is found high up on the 
overhanging rock wall, in a part of the cave that could only be accessed by artists when standing on a large boulder on the scree slope and reaching up. This localised panel is segregated spatially from the main body of artwork in the cave, marking the cave entrance, and the charcoal drawings found here would appear, on both spatial and stylistic grounds, to represent a single artistic event. The two radiocarbon-dated charcoal drawings from this panel are part of a spatially and stylistically close-knit set of 'Generalised Anthropomorphs' and 'Anthropomorphs with Inverted V-Headdresses' (see David et al. 1997 for details of the Mitchell-Palmer region's rock art). About $1 \mathrm{~m}$ away around the corner of the same rock that protrudes down from the ceiling, an 'Anthropomorph with Knobbed Headdress', drawn in a similar manner to the other two radiocarbon-dated anthropomorphs, was also radiocarbon dated. Each of these three radiocarbon determinations overlaps at two standard deviations, and indicates that this panel and the nearby paintings were probably all drawn around $1500 \mathrm{BP}$.

The fourth radiocarbon-dated rock drawing is located in a protected part of the site in semi-dark conditions on the vertical wall of a large limestone pillar close to the back wall. It consists of a set of 'Radiating Lines' (see David et al. 2001:112 for a tracing of this drawing). The radiocarbon date for this image is $1010 \pm 60 \mathrm{BP}$ (OZC608).

The two major implications from the radiocarbon dates at Hay Cave are that, firstly, artistic activity took place late during the late Holocene, during a span of time when cultural activity (including the application of pigment art on rock) and demographic conditions appear to have reached a peak across much of north Queensland (see David and Chant 1995). And, secondly, that the artistic activity at Hay Cave took place at a point in time with no in-situ evidence of human presence in that part of the site we have excavated. For example, even when the outof-sequence ${ }^{14} \mathrm{C}$ sample OZD010 is taken into account, there appears to be an absence of sedimentation and cultural deposition between ca. $1500 \mathrm{BP}$ and $1000 \mathrm{BP}$. Therefore, it could be argued that at that time the cultural significance of the site shifted, the cave being no longer suitable for habitation, rather being reserved for artistic practices and their symbolic and cosmological associations.

\section{Discussion}

\section{Palaeoenvironmental trends at Hay Cave}

Based on the incidence of grassland and open forest/woodland animal taxa, Roche (1999:111-13) concluded that gross vegetation patterns in the Hay Cave area remained generally stable through time (relative to more coastal parts of southeast Cape York Peninsula). That is, throughout the past 30,000 years, the Hay Cave environment retained its patchwork of open forest/woodland and grassland with small pockets of wet forest vegetation amongst the karst towers.

Nevertheless, some changes did take place. Between ca. 19,000 BP and 16,000 BP, low proportions of open forest/woodland animal taxa indicate more arid conditions than previously, but less dramatic changes than have been described for the Atherton Tableland some $150 \mathrm{~km}$ to the southeast (cf. Butler 1998:5; Kershaw 1986:48). This drier period is followed by an increase in open forest/woodland animal taxa between ca. 15,000 BP and 12,000 BP, suggesting increasing precipitation (Roche 1999). Rowe's (1998) complementary land-snail shell and calciumcarbonate concretion data also indicate dry conditions leading into the terminal Pleistocene/ Holocene boundary, followed by a period of increased-to-peak precipitation encompassing the early and mid Holocene ca. 13,600-3100 BP. Peak humid conditions during this time began shortly after ca. 13,600-13,420 BP. The sediments of the mid-Holocene period at Hay Cave include the phase ca. 7000-6000 BP, as indicated by the Australian brush-turkey (Alectura lathami) egg-shell cluster C. 
At Hay Cave, the onset of increased precipitation (and end of peak aridity) in the terminal Pleistocene (between ca. 15,000 BP and 12,000 BP) generally overlaps in timing with that of other parts of southeast Cape York Peninsula ca. 13,000-10,000 BP (Torgensen et al. 1988:259), although its commencement at Hay Cave may be slightly earlier. The analysis of land-snail shell (Rowe 1998) present throughout the Hay Cave sequence, indicates an unbroken association with vine thicket. While the karst formations may have acted as refugia for such relatively humid forest vegetation, low quantities of rainforest/wet forest vertebrate taxa at the site suggest that humid forest or vine thicket itself was never expansive across the region during the past 30,000 years. Here, relatively wet forest/vine thicket may have been restricted mainly to small refugia like the karsts and creek edges, even during the wetter terminal-Pleistocene to mid-Holocene period.

The past ca. 3000 years, by way of contrast, were generally drier, with Rowe's land-snail shell data indicating that a short wetter phase occurred also between ca. $900 \mathrm{BP}$ and $600 \mathrm{BP}$, suggesting overall general climatic variability. Open forest/woodland vertebrate taxa accordingly show a marginal decrease from the prior wetter period of the early to mid Holocene.

\section{Cultural trends at Hay Cave}

Drawing all the material together, we have the following sequence. People first started using Hay Cave around 30,000 BP or shortly beforehand, but at first, human occupation was low. The following, increasingly drier, periods that led into the glacial maximum (ca. 19,500-16,000 BP), continued to experience low levels of site use by people. Murids are absent during this phase of peak aridity. Throughout this long period of time, the cave was occupied more frequently by animals, including predatory birds. These trends were measured by the various indices deposition rates of sediment, animal bone, mussel shell and egg shell; and construction rates of hearths, incorporating charcoal, burnt earth and structural features. These indicate that low levels of site use continued until around 15,000 BP when evidence of human presence begins to increase. This was a time of open forest/woodland and grassland communities.

The first noticeable long-term rise in occupation by people coincided with increasing rates of precipitation between ca. 15,000 $\mathrm{BP}$ and 12,000 $\mathrm{BP}$ that continued into the early to mid Holocene until around $3100 \mathrm{BP}$. With the onset of increasing precipitation at this time, people began to use the cave more often and there is a peak in the incidence of open forest/woodland animal taxa. Murids also are present, indicating a continuation of mixed human and nonhuman use of the cave.

Patterns of human occupation at the site are unclear to some extent during the early to mid Holocene due to stratigraphic disturbances. The significant rise in levels of precipitation between ca. 13,600 BP and $3100 \mathrm{BP}$ (Rowe 1998:78-79) may have resulted in disturbance to the cave's deposits, as indicated by larger sediment particle sizes and high quantities of calcium-carbonate concretions, together with increases in land-snail shell. To what extent people continued using the cave throughout this lengthy period is uncertain, although the presence of cultural remains in those deposits (often encrusted in thick calcium-carbonate concretions) testifies against total abandonment. During this period, radiocarbon dates on charcoal and egg shell at Hay Cave, and chronological estimates based on degrees of isoleucine epimerisation among Australian brush-turkey egg shells, point to depositional events around 12,000 BP, between 7000-6000 $\mathrm{BP}$ and around $5400 \mathrm{BP}$.

The most intensive period of occupation of the cave was during the late Holocene, between ca. 3100 BP until the near-present, a period of drier, changeable climate. This peak period of human use of Hay Cave between ca. $3000 \mathrm{BP}$ and $150 \mathrm{BP}$ is shown by all indices, including the fastest deposition rates of sediments, and also of a broad class of cultural materials, including peak proportions of macropod bone and high calcined bone frequencies. Attempts were made 
during this time to ration and conserve stone, indicating that demands for lithic raw materials were high relative to availability. The decline in murids may also be linked to increased human presence. Indeed, murids are only present in XU13, coinciding with a short wet phase dated to within ca. 900-600 BP, suggesting that wetter conditions may have then limited people's use of the damp cave, leaving it to other predators including birds. There is no strong evidence here to link murids predominantly to human diet.

It is during this recent period also that rock art - in particular pigment art - makes its appearance. Around $1500 \mathrm{BP}$, artists began to use the site in a new way, and in doing so, ceased to live in it - or at least in the area we excavated, using it instead in a specialised way. The symbolic marking of the cave with charcoal anthropomorphs at its entrance, and a broader range of designs within its chambers, signals the onset of a new system of territorial place marking and cosmological referencing that point to a changing social world.

\section{Regional trends and patterns of site use}

General comparisons can be drawn between the chronological trends observable at Hay Cave and trends derived from regional archaeological data. Long-term trends for southeast Cape York Peninsula have been obtained in three ways by analysing temporal patterning in (a) all radiocarbon dates, (b) the number of occupied sites, and (c) the rates of site establishment, at a regional scale and over a 30,000-year period (David and Lourandos 1997; Lourandos and David 1998, 2002). While accepting the generalised nature of all these trends and their methodological limitations, they nevertheless offer the opportunity to draw comparisons between different kinds of data sets and between data derived at different analytical scales: in this case, comparing site trends with regional trends.

A general comparison between the Hay Cave trends and the regional trends shows some strong similarities. In both, rates of site and regional land use by people are low from before 30,000 BP until after the Last Glacial Maximum, with noticeable increases in all indices during the terminal Pleistocene after ca. 15,000 BP, and with even higher rises in the late Holocene after ca. 3000 BP until recent times. These trends apply both to highly durable materials such as stone artefacts and to hard organic items such as animal bones and shell at sites with good preservation. Similar trends are observed also in other site data, including the incidence of hearths, evidence for treadage-induced disturbance, and overall sedimentation rates. They also apply to rock art, which evidences major quantitative increases in pigment art creation (see below). The general trend, therefore, is consistent across the varied lines of evidence (e.g. stone artefacts, faunal remains, rock art) and across analytical scales (site and regional).

In this context, and at both site and regional scales, the glacial maximum is clearly associated with changes to environment and site use. There are, however, no signs of disuse or abandonment of Hay Cave at this time, as occur at some other sites in the region. During the Last Glacial Maximum, the karst towers may have served as more humid locations, to which people periodically retreated, within a generally drier landscape. This pattern of increased use during the Last Glacial Maximum is observable at the sites of Fern Cave, Hearth Cave and Sandy Creek 1, all located near permanent sources of water (Morwood and Hobbs 1995:180; David and Lourandos 1997:6). Likewise, Hay Cave lies close to Limestone Creek, assumed to have been active during the Last Glacial Maximum.

The early Holocene period remains less clear to some extent, at both local (Hay Cave) and regional scales, due to sediments being affected by post-depositional taphonomic factors such as lag deposits caused by increased precipitation levels in most sites excavated so far. In addition to Hay Cave, this problem has been documented also at Walkunder Arch Cave (Campbell 1982:65), Green Ant Shelter (Flood and Horsfall 1986:39), Sandy Creek 1 (Morwood and Hobbs 1995:78) and Fern Cave (David and Chant 1995:401). In contrast to this issue, however, 
the general regional trends for this same early-mid Holocene period indicate significant rises in site establishment and use (David and Lourandos 1997).

The Hay Cave sequence, therefore, appears to reflect the site's particular location, and individual characteristics, within the environmentally varied region of southeast Cape York Peninsula. Throughout its occupational history, the Hay Cave environment appears to have remained largely a mixture of open forest/woodland and grassland, with small pockets of dry rainforest vegetation in the immediate vicinity of karst towers. Overall environmental change during the Last Glacial Maximum, for example, was less marked than has been described for the Atherton Tableland on the eastern plateau (Kershaw et al. 2007). In general, Hay Cave reflects a more stable and drier climate when compared with the more humid areas some 150 $\mathrm{km}$ further to the southeast, towards the higher parts of the Great Dividing Range and the coast. Lying within a rain shadow, the Hay Cave area appears to have been shielded from the more dramatic climatic oscillations experienced in more coastal regions nearby (see also Rowe 1998:78; Roche 1999:115-25). Nevertheless, the Mitchell-Palmer region (including Hay Cave) witnessed similar directions of environmental change to those further in the east.

\section{Regional trends and patterns: Rock art}

We have elsewhere argued that the past 2000 years in particular saw an increased regionalisation of social practice across southeast Cape York Peninsula (David and Chant 1995; David and Lourandos 1998, 1999; David 2002). In Princess Charlotte Bay and its neighbouring Flinders Island group, the late-Holocene art includes numerous figurative paintings of moths/butterflies and zoomorphs with crescent heads (David and Chant 1995). Close by to the south, in the Koolburra Plateau, large numbers of paintings of echidna-human therianthropes predominate (Flood 1987). Across the Kennedy River, just off the eastern edge of the Koolburra Plateau, the Laura sandstones are richly decorated with a broad range of anthropomorphs and, to a lesser degree, zoomorphs, many of which are life-sized and contain elaborate decoration in bichrome or polychrome (e.g. Cole 1992; Morwood and Hobbs 1995). To the immediate south of the Laura sandstones, in the Mitchell-Palmer limestone belt, generalised anthropomorphs abound, many painted upside-down (David et al. 1997). To the south, neighbouring the Mitchell-Palmer limestones, are the Bonney Glen granite boulders, where again, generalised anthropomorphs and zoomorphs occur (David 1998a). Immediately to the south of the Mitchell and Walsh Rivers is Ngarrabullgan, a large, cliff-lined mountain where the art suddenly and dramatically contrasts with that of all its northern neighbours (David 1998b): here, no more do we find a predominance of figurative paintings of human and animal shapes. Instead, we find linear abstract designs, such as single and composite lines, circles and their variants, radiating and grid designs. In the Mungana, Chillagoe, and Almaden areas on the other side of the Featherbed Ranges and to the immediate southwest of Ngarrabullgan - in a similar geological setting to the Mitchell-Palmer limestone belt further to the north we again find a predominance of abstract linear paintings (e.g. David and David 1988). In the Davies Creek region on the edge of the rainforest further to the east, there is a predominance of localised figurative forms in the shape of generalised anthropomorphs with upraised arms and down-turned legs, in what some authors have described as a 'dancing' style (Clegg 1978; see David and Chant 1995, and David and Lourandos 1998 for reviews of regional rock-art conventions). There is, therefore, significant late-Holocene regionalism in southeast Cape York Peninsula's rock art. During that time, individual sites began to be used in new ways, adding to our understanding of social process. Socio-territorial changes documented for the region thus now also appear to be associated with changes in the meaning of specific places. We suggest that the increased regionalism of the past two millennia took place as territorial constrictions, and were inscribed by local artistic practices and legitimated by increasingly localised cosmological 
referents to local ancestral spirit beings that came to be known ethnographically as 'Dreamings'. These Dreamings became referents to 'country'; to landscapes populated not only by people but also ancestors and spirit-forces that gave the land its particular character in language and culture, as was apparent during the early European contact period. The portrayal of Dreaming beings and spirit-forces in rock art during the past 1500 years at Hay Cave, and the past 3000-2000 years across southeast Cape York Peninsula, at a time coincident with significant increases in site and regional land use, suggests the onset of population increases and social and territorial restructuring (David and Lourandos 1997, 1998, 1999), in association with a new or transforming cosmology; akin to that which through time became the ethnographic Dreaming system of this region. The predominance of anthropomorphs in the rock art of the entire Mitchell-Palmer region is a graphic articulation of this process of territorial and cosmological regionalisation expressed in site-specific depictions and use.

\section{Conclusions}

At Hay Cave, long-term archaeological trends have been characterised in a number of ways by employing a multifarious approach, composed of a range of separate indices and trends. The overall general archaeological trend is consistent across the varied lines of evidence and across different analytical scales, both site-specific and regional. At Hay Cave, generalised, long-term archaeological trends compare favourably with general, regional temporal trends derived from separate data sets. In both, rates of site and regional land use by people are low from before ca. 30,000 BP until after the Last Glacial Maximum, with noticeable increases in all indices during the terminal Pleistocene after ca. 15,000 BP, and with even higher rises in the late Holocene after ca. $3000 \mathrm{BP}$ until recent times.

At Hay Cave, palaeoenvironmental trends were analysed by use of the land-snail shells and vertebrate faunal material and these also reflected the wider, general regional trends, while at the same time presenting a more localised focus. Lying further inland, Hay Cave falls outside the more humid coastal belt and its more dramatic climatic oscillations. The broader relationships between the long-term, regional palaeoenvironmental trends and cultural patterns, as well as human demographic trends, have been discussed elsewhere (cf. David and Lourandos 1997, 1998, 1999; Lourandos and David 2002). At Hay Cave, the rock art, for example, is clearly a local manifestation of the regionalised rock-art patterns of the past 2000 years found across the wider Cape York Peninsula area that have been viewed in terms of increased and denser Aboriginal populations (David and Lourandos 1998). In all, these spatio-temporal patterns of human behaviour observed through the analysis of individual sites and their broader regional patterning - incorporating emplaced art and deposition rates of varied cultural materials - amount to a spatial history of Aboriginal Australia.

\section{Acknowledgements}

We thank Kuku Yalanji representative Qawanji and his family; Bob Bultitude, Dave Currie, Les Hall, Lana Little and Andy Spate for fieldwork assistance; Mrs Wilson and George Wilson for permission to excavate on their land; Earthwatch for funding the fieldwork; Bob Bultitude for his generous time and advice with stone artefact raw material identifications; AINSE for funding the radiocarbon determinations; Toby Wood (Monash University) for drafting the figures. BD thanks the School of Geography and Environmental Science at Monash University for support, and the Australian Research Council for a QEII Fellowship to enable the writing up of this paper. Thanks also to Simon Haberle and anonymous referees for comments on an earlier version of this paper. 


\section{References}

Balme, J., Merilees, D. and Porter, J.K. 1978. Late Quaternary mammal remains spanning about 30,000 years from excavations in Devil's Lair, Western Australia. Journal of the Royal Society of Western Australia 61(2):33-65.

Bowdler, S. 1984. Hunter Hill, Hunter Island. Canberra: The Australian National University.

Butler, D. 1998. Environmental change in the Quaternary. In David B. (ed), Ngarrabullgan: Geographical Investigations in Djungan Country, Cape York Peninsula. Monash Publications in Geography and Environmental Science 51:78-97. Monash University, Clayton.

Campbell, J.B. 1982. New radiocarbon results for north Queensland prehistory. Australian Archaeology 14:62-66.

Clarke S.J. 2005. Isoleucine epimerisation and stable isotope ratio studies of cassowary, megapode and Aepyornis egg shells: biogeochemical and palaeoenvironmental implications. Unpublished $\mathrm{PhD}$ thesis, University of Wollongong. Available online at http://www. library.uow.edu.au/theses/

Clarke, S.J., Miller, G.H., Murray-Wallace, C.V., David, B. and Pasveer, J.M. 2007. The geochronological potential of isoleucine epimerisation in cassowary and megapode eggshells from archaeological sites. Journal of Archaeological Science 34:1051-63.

Clegg, J. 1978. Mathesis words, mathesis pictures. Unpublished MA (Honours) thesis, University of Sydney, Sydney.

Cole, N. 1992. 'Human' motifs in the rock paintings of Jowalbinna, Laura. In: McDonald, J. and Haskovec, I.P. (eds), State of the Art: Regional Rock Art Studies in Australia and Melanesia, pp. 164-73. Australian Rock Art Research Association, Melbourne.

David, B. 1984a. Walkunder Arch Cave: a faunal report. Australian Archaeology 18:40-54.

David, B. 1984b. Man ws Dingo: the identification of bone remains from archaeological sites with specific reference to Walkunder Arch Cave, Chillagoe, north-east Queensland. Brisbane: Department of Aboriginal and Islander Affairs Archaeological Branch.

David, B. 1990. How was this bone burnt? Tempus 2:65-79.

David, B. 1998a. Rock art of southeast Cape York Peninsula: Bonney Glen Station. Memoirs of the Queensland Museum 1:127-36.

David, B. 1998b. The rock art. In: David, B. (ed), Ngarrabullgan: Geographical Investigations in Djungan Country, Cape York Peninsula. Monash Publications in Geography and Environmental Science 51, pp. 143-56. Monash University, Clayton.

David, B. 2002. Landscapes, Rock-art and the Dreaming: An Archaeology of Preunderstanding. Leicester University Press, London.

David, B., Armitage, R.A., Rowe, M.W. and Lawson, E. 2001. Landscapes in transition? New radiocarbon dates on cave paintings from the Mitchell-Palmer limestone belt (northeastern Australia). American Indian Rock Art 27:107-116.

David, B, and Chant, D. 1995. Rock art and regionalization in north Queensland prehistory. Memoirs of the Queensland Museum 37, 2:357-528.

David, B. and Dagg, L. 1993. Two Caves. Memoirs of the Queensland Museum 33:143-62.

David, B. and David, M. 1988. Rock pictures of the Chillagoe-Mungana limestone belt, north Queensland. Rock Art Research 5:147-56.

David, B. and Lourandos, H. 1997. 37,000 years and more in tropical Australia: investigating long-term archaeological trends in Cape York Peninsula. Proceedings of the Prehistoric Society 63:1-24.

David, B. and Lourandos, H. 1998. Rock art and socio-demography in north-eastern Australian prehistory. World Archaeology 30:193-219.

David, B. and Lourandos, H. 1999. Landscape as mind: land use, cultural space and change in north Queensland prehistory. Quaternary International 59:107-123. 
David, B., Walt, H., Lourandos, H., Rowe, M., Brayer, J. and Tuniz, C. 1997. Ordering the rock paintings of the Mitchell-Palmer limestone zone (Australia) for AMS dating. The Artefact 20:57-72.

Day, R.W., Whitaker, W.G., Murray, C.G., Wilson I.H. and Grimes, K.G. 1983. Queensland Geology: A companion volume to the 1:2,500,000 scale geological map (1975). Geological Survey of Queensland Publication 383, Brisbane.

Dogmagala, J. and Fordham, B.G. 1997. Silurian-Early Devonian: Chillagoe Formation (Hodgkinson Province). In: Bain, J.H.C. and Drapper, J.J. (eds), North Queensland Geology. AGSO Bulletin 240/Queensland Geology, Brisbane.

Fensham, R.J. 1995. Floristics and environmental relations of inland dry rainforests in north Queensland, Australia. Journal of Biogeography 22:1047-1063.

Fensham, R.J. 1996. Land clearance and conservation of inland dry rainforest in north Queensland, Australia. Biological Conservation 75:289-298.

Flood,J.1987. Rock art of the Koolburra Plateau, north Queensland. Rock Art Research 4(2):91126.

Flood, J. and Horsfall, N. 1986. Excavation of Green Ant and Echidna shelters, Cape York Peninsula. Queensland Archaeological Research 3:4-64.

Galloway, R.W., Gunn, R.H. and Stony, R. 1970. Lands of the Mitchell-Normanby Area. CSIRO Land Research Series 26, CSIRO, Canberra.

Gould, S.J. 1984. Covariance sets and ordered geographic variation in Cerion from Aruba, Bonaire and Curacao: a way of studying nonadaptation. Systematic Zoology 33:217-237.

Grayson, D.K. 1984. Quantitative Zooarchaeology. New York: Academic Press.

Hall, L., Whittier, J. and Macrokanis, C. 1996. The fauna surveys. Unpublished report to Bruno David for the Earthwatch Institute, Melbourne.

Hiscock, P. 1988. Prehistoric settlement patterns and artefact manufacture at Lawn Hill, northwest Queensland. PhD thesis, Department of Anthropology and Sociology, University of Queensland, St. Lucia.

Holden, A. 1999. A technological analysis of the lithic assemblage from Hay Cave, SE Cape York Peninsula: considering diachronic variations in patterns of 'intensity of site use'. Unpublished B.A. (Hons) thesis, University of Queensland, St Lucia.

Hughes, P.J. and Djohadze, V. 1980. Radiocarbon dates from archaeological sites on the South Coast of New South Wales and the use of depth/age curves. Occasional papers in prehistory 1, Australian National University, Canberra.

Kahn, T.P. and Lawrie, B.C. 1987. Vine thickets of the inland Townsville region. In: Australian Heritage Commission (ed), The Rainforest Legacy: Australian National Rainforest Study. Australian Government Publishing Service, Canberra. pp. 159-201.

Kershaw, A.P. 1986. Climate change and Aboriginal burning in north-east Australia during the last two glacial/interglacial cycles. Nature 322(3):47-49.

Kershaw, A.P. 1994. Pleistocene vegetation of the humid tropics of northeastern Queensland, Australia. Palaeogeography, Palaeoclimatology, Palaeoecology 109:339-412.

Kershaw,A.P.,McKenzie, G.M. and McMinn,A.1993. A Quaternaryvegetation of northeastern Queensland from the pollen analysis of ODP site 820. In: McKenzie, J.A., Davie, P.J. and Palmer-Johnston, A. (eds), Proceedings of the Ocean Drilling Program, Scientific Results 133:107-114.

Kershaw, A.P., Haberle, S.J., Turney, CS.M. and Bretherton, S.C. (eds), 2007. Environmental bistory of the humid tropics region of north-east Australia. Special Issue Palaeogeography, Palaeoclimatology, Palaeoecology 251(1):1-173. 
Lamb, L. 1994. A technological analysis of lithic material from Fern Cave, Queensland. B.A. (Hons) thesis, Department of Anthropology and Sociology, University of Queensland, St. Lucia.

Lourandos, H. and David B. 2002. Long-term archaeological and environmental trends: a comparison from late-Pleistocene-Holocene Australia. In: Kershaw, P., David, B., Tapper, N., Penny, D. and Brown, J. (eds), Bridging Wallace's line: the Environmental and Cultural History and Dynamics of the SE-Asian-Australian Region, pp. 307-338. Advances in Geoecology 34, Catena Verlag GMBH, Reiskirchen.

Lourandos, H. and David, B. 1998. Comparing long-term archaeological and environmental trends: north Queensland, arid and semiarid Australia. The Artefact 21:105-114.

Lyman, R.L. 1994. Vertebrate Taphonomy. Cambridge: Cambridge University Press.

McCormac, F.G., Hogg, A.G., Blackwell, P.G., Buck, C.E., Higham, T.F.G., and Reimer, P.J. 2004. SHCal04 Southern Hemisphere Calibration 0-11.0 cal Kyr BP. Radiocarbon 46, 1087-1092.

Macrokanis, C. 1996. Journal of the University of Queensland and Earthwatch expedition to Mitchell-Palmer valley from a zoological perspective. Unpublished report to Bruno David for the Earthwatch Institute, Melbourne.

Mitchell, S. 1988. Chronological change in intensity of site use: a technological analysis. B.A. (Hons) thesis, Department of Anthropology and Sociology, University of Queensland, St. Lucia.

Morwood,M.J. and Hobbs,D.R.(eds), 1995. Quinkan prehistory: the archaeology of Aboriginal art in S.E. Cape York Peninsula. Tempus 3. University of Queensland, Brisbane.

Odhner, N.H. 1917. Results of Dr. E. Mjöberg's Swedish scientific expeditions to Australia 1910-1913. XVII. Mollusca. Kungliga Svenska Vetens Kapsakademiens Handlingar 52(16):1115.

Roche, N. 1999. Reading the bones: an analysis of cultural and palaeoenvironmental trends at Hay Cave, S.E. Cape York. Unpublished B.A. (Hons) thesis, University of Queensland, St Lucia.

Rowe, C. 1998. The value of land snails for reconstruction of palaeoenvironments in northern Queensland. Unpublished B.A. (Hons) thesis, Monash University, Clayton.

Rowe, C., Stanisic, J., David, B. and Lourandos, H. 2001. The helicinid land snail Pleuropoma extincta (Odhner, 1917) as an environmental indicator in archaeology. Memoirs of the Queensland Museum 46(2):741-70.

Shipman, P., Foster, G. and Schoeninger, M. 1984. Burnt bones and teeth: an experimental study of colour, morphology, crystal structure and shrinkage. Journal of Archaeological Science 11:307-325.

Solem, A. and Christensen, C.C. 1984. Camaenid land snail reproductive cycle and growth patterns in semi-arid areas of northwest Australia. Australian Journal of Zoology 32:47191.

Stanisic, J. 1997. Land snails of the Chillagoe Limestones. Australian Shell Nerws, 96(Oct):3-6.

Stanisic, J. and Ingram, G. 1998. Sandstone, snails and slaters: invertebrate fauna. In: David, B. (ed), Ngarrabullgan: Geographical investigations in Djungan country, Cape York Peninsula, pp. 112-18. Monash Publications in Geography and Environmental Science, Monash University, Clayton.

Stuiver, M. and Reimer, P.J. 1993. Extended 14C database and revised CALIB radiocarbon calibration program. Radiocarbon 35:215-230.

Terlich, N.J.1998. Teeth, bones and other indices. Unpublished B.A.(Hons) thesis, Department of Anthropology and Sociology, University of Queensland, St. Lucia.

Tillier, S. 1981. Clines, convergence and character displacement in New Caledonian diplommatinids (land prosobranchs). Malacologia 21:177-208. 
Torgerson, T., Luly, J., De Deckker, P., Jones, M.R., Searle, D.E., Chivas, A.R. and Ullman, W.J. 1988. Late Quaternary environments of the Carpentaria Basin, Australia. Palaeogeography, Palaeoclimatology, Palaeoecology 67:245-61.

Appendix 1. The rock pictures of Hay Cave; motif types follow David et al. (1997).

\begin{tabular}{|c|c|c|c|c|c|c|}
\hline $\begin{array}{c}\text { Picture } \\
\#\end{array}$ & Motif type & Engraving & $\begin{array}{l}\text { Drawing or } \\
\text { painting colour }\end{array}$ & $\begin{array}{l}\text { Maximum } \\
\text { length } \\
\text { (cm) }\end{array}$ & $\begin{array}{l}{ }^{14} \text { C date } \\
\text { (BP) }\end{array}$ & Comments \\
\hline 1 & $\begin{array}{c}\text { generalised } \\
\text { anthropomorph }\end{array}$ & & black & & & \\
\hline 2 & $\begin{array}{c}\text { generalised } \\
\text { anthropomorph }\end{array}$ & & black & & & male \\
\hline 3 & $\begin{array}{c}\text { generalised } \\
\text { anthropomorph }\end{array}$ & & black & & & \\
\hline 4 & $\begin{array}{c}\text { generalised } \\
\text { anthropomorph }\end{array}$ & & black & & & \\
\hline 5 & $\begin{array}{c}\text { anthropomorph } \\
\text { with inverted } \\
\text { V-headdress }\end{array}$ & & black & & & male \\
\hline 6 & $\begin{array}{c}\text { anthropomorph } \\
\text { with inverted } \\
\text { V-headdress }\end{array}$ & & black & & & male \\
\hline 7 & $\begin{array}{c}\text { generalised } \\
\text { anthropomorph }\end{array}$ & & black & & & \\
\hline 8 & $\begin{array}{c}\text { anthropomorph } \\
\text { with inverted } \\
\text { V-headdress }\end{array}$ & & black & & & male \\
\hline 9 & $\begin{array}{c}\text { aeneralised } \\
\text { anthropomorph }\end{array}$ & & black & & & \\
\hline 10 & $\begin{array}{c}\text { anthropomorph } \\
\text { with inverted } \\
\text { V-headdress }\end{array}$ & & black & & $\begin{array}{l}1480 \pm 50 \\
(0 Z 0427)\end{array}$ & male \\
\hline 11 & $\begin{array}{l}\text { linear non- } \\
\text { figurative }\end{array}$ & & black & & & \\
\hline 12 & $\begin{array}{l}\text { linear non- } \\
\text { figurative }\end{array}$ & & black & & & \\
\hline 13 & $\begin{array}{c}\text { generalised } \\
\text { anthropomorph }\end{array}$ & & black & & & \\
\hline 14 & $\begin{array}{c}\text { anthropomorph } \\
\text { with inverted } \\
\text { V-headdress }\end{array}$ & & black & 33 & $\begin{array}{l}1700 \pm 90 \\
(0 Z D 425)\end{array}$ & \\
\hline 15 & $\begin{array}{c}\text { generalised } \\
\text { anthropomorph }\end{array}$ & & black & & & \\
\hline 16 & $\begin{array}{l}\text { generalised } \\
\text { zoomorph }\end{array}$ & $x$ & & 68 & & $\begin{array}{l}\text { lizard with } \\
\text { crescent-head } \\
\text { shape }\end{array}$ \\
\hline 17 & $\begin{array}{l}\text { linear non- } \\
\text { figurative }\end{array}$ & $x$ & & 25 & & \\
\hline 18 & $\begin{array}{c}\text { generalised } \\
\text { anthropomorph }\end{array}$ & & red & 31 & & male \\
\hline 19 & $\begin{array}{c}\text { generalised } \\
\text { anthropomorph }\end{array}$ & & red & 47 & & \\
\hline 20 & $\begin{array}{c}\text { generalised } \\
\text { anthropomorph }\end{array}$ & & orange & 48 & & male \\
\hline
\end{tabular}


Appendix 1. Continued

\begin{tabular}{|c|c|c|c|c|c|c|}
\hline $\begin{array}{c}\text { Picture } \\
\quad \#\end{array}$ & Motif type & Engraving & $\begin{array}{l}\text { Drawing or } \\
\text { painting colour }\end{array}$ & $\begin{array}{l}\text { Maximum } \\
\text { length } \\
\text { (cm) }\end{array}$ & $\begin{array}{l}{ }^{14} \text { C date } \\
\text { (BP) }\end{array}$ & Comments \\
\hline 21 & drawn area & & black & 9 & & $\begin{array}{l}\text { his motif } \\
\text { type was not } \\
\text { described in } \\
\text { David et al. } \\
\text { 1997. It consists } \\
\text { of numerous } \\
\text { drawn lines } \\
\text { covering a } \\
\text { small area a } \\
\text { few centimetres } \\
\text { square }\end{array}$ \\
\hline 22 & drawn area & & black & 10 & & See Picture 21 \\
\hline 23 & $\begin{array}{c}\text { generalised } \\
\text { anthropomorph } \\
\text { with fingers } \\
\text { and/or toes }\end{array}$ & & red & 56 & & \\
\hline 24 & $\begin{array}{c}\text { generalised } \\
\text { anthropomorph }\end{array}$ & & red & 54 & & male \\
\hline 25 & $\begin{array}{c}\text { generalised } \\
\text { anthropomorph } \\
\text { with fingers } \\
\text { and/or toes }\end{array}$ & & $\begin{array}{l}\text { white outline- } \\
\text { red infill }\end{array}$ & 31 & & $\begin{array}{c}\text { upside-down } \\
\text { anthropomorph }\end{array}$ \\
\hline 26 & $\begin{array}{l}\text { generalised } \\
\text { zoomorph }\end{array}$ & & black & & & lizard-shape \\
\hline 27 & $\begin{array}{c}\text { complex } \\
\text { anthropomorph }\end{array}$ & & $\begin{array}{l}\text { white outline- } \\
\text { red infill-white } \\
\text { internal } \\
\text { decoration }\end{array}$ & 49 & & $\begin{array}{l}\text { upside-down } \\
\text { male }\end{array}$ \\
\hline 28 & $\begin{array}{l}\text { generalised } \\
\text { anthropomorph } \\
\text { with fingers } \\
\text { and/or toes }\end{array}$ & & red & 54 & & male \\
\hline 29 & $\begin{array}{c}\text { generalised } \\
\text { anthropomorph }\end{array}$ & & red & 35 & & \\
\hline 30 & $\begin{array}{c}\text { generalised } \\
\text { anthropomorph }\end{array}$ & & red & са. 32 & & male \\
\hline 31 & $\begin{array}{c}\text { generalised } \\
\text { anthropomorph } \\
\text { with fingers } \\
\text { and/or toes }\end{array}$ & & red & 44 & & female \\
\hline 32 & $\begin{array}{c}\text { generalised } \\
\text { anthropomorph }\end{array}$ & & red & 53 & & \\
\hline 33 & $\begin{array}{c}\text { generalised } \\
\text { anthropomorph }\end{array}$ & & red & 44 & & female \\
\hline 34 & $\begin{array}{c}\text { anthropomorph } \\
\text { with knobbed } \\
\text { headdress }\end{array}$ & & red & 80 & & \\
\hline 35 & $\begin{array}{c}\text { anthropomorph } \\
\text { with knobbed } \\
\text { headdress }\end{array}$ & & red & 73 & & \\
\hline 36 & $\begin{array}{c}\text { generalised } \\
\text { anthropomorph }\end{array}$ & & red & 72 & & male \\
\hline
\end{tabular}


Appendix 1. Continued

\begin{tabular}{|c|c|c|c|c|c|c|}
\hline $\begin{array}{c}\text { Picture } \\
\#\end{array}$ & Motif type & Engraving & $\begin{array}{l}\text { Drawing or } \\
\text { painting colour }\end{array}$ & $\begin{array}{l}\text { Maximum } \\
\text { length } \\
\text { (cm) }\end{array}$ & $\begin{array}{l}{ }^{14} \mathrm{C} \text { date } \\
\text { (BP) }\end{array}$ & Comments \\
\hline 37 & $\begin{array}{c}\text { generalised } \\
\text { anthropomorph } \\
\text { with fingers } \\
\text { and/or toes }\end{array}$ & & red & 84 & & $\begin{array}{l}\text { upside-down } \\
\text { female }\end{array}$ \\
\hline 38 & $\begin{array}{c}\text { generalised } \\
\text { anthropomorph }\end{array}$ & & black & 31 & & male \\
\hline 39 & grid & & black & 40 & & \\
\hline 40 & radiating lines & & black & 31 & $\begin{array}{c}1010 \pm 60 \\
(0 z C 608)\end{array}$ & \\
\hline 41 & bird track & $x$ & & 16 & & trident with heel \\
\hline 42 & bird track & $x$ & & 15 & & \\
\hline 43 & $\begin{array}{l}\text { generalised } \\
\text { anthropomorph } \\
\text { with fingers } \\
\text { and/or toes }\end{array}$ & & red & 20 & & $\begin{array}{l}\text { upside-down } \\
\text { anthropomorph }\end{array}$ \\
\hline 44 & $\begin{array}{c}\text { anthropomorph } \\
\text { with knobbed } \\
\text { headdress }\end{array}$ & & black & 30 & $\begin{array}{c}1570 \pm 110 \\
(0 Z C 848)\end{array}$ & male \\
\hline 45 & $\begin{array}{c}\text { anthropomorph } \\
\text { with inverted } \\
\text { V-headdress }\end{array}$ & & black & 20 & & \\
\hline 46 & $\begin{array}{l}\text { linear non- } \\
\text { figurative }\end{array}$ & & red & 20 & & \\
\hline 47 & indeterminate & & black & & & \\
\hline 48 & indeterminate & & red & & & \\
\hline 49 & $\begin{array}{c}\text { generalised } \\
\text { anthropomorph }\end{array}$ & & black & & & male \\
\hline 50 & indeterminate & & black & & & \\
\hline 51 & $\begin{array}{c}\text { anthropomorph } \\
\text { with inverted } \\
\text { V-headdress }\end{array}$ & & black & & & \\
\hline 52 & $\begin{array}{c}\text { generalised } \\
\text { anthropomorph }\end{array}$ & & black & & & \\
\hline 53 & $\begin{array}{c}\text { generalised } \\
\text { anthropomorph }\end{array}$ & & black & & & male \\
\hline 54 & $\begin{array}{c}\text { generalised } \\
\text { anthropomorph }\end{array}$ & & black & & & \\
\hline 55 & $\begin{array}{c}\text { generalised } \\
\text { anthropomorph }\end{array}$ & & black & & & \\
\hline 56 & $\begin{array}{c}\text { generalised } \\
\text { anthropomorph }\end{array}$ & & black & & & male \\
\hline 57 & $\begin{array}{c}\text { generalised } \\
\text { anthropomorph }\end{array}$ & & black & & & \\
\hline 58 & $\begin{array}{c}\text { generalised } \\
\text { anthropomorph }\end{array}$ & & black & & & \\
\hline 59 & $\begin{array}{l}\text { linear non- } \\
\text { figurative }\end{array}$ & & red & 29 & & \\
\hline 60 & $\begin{array}{c}\text { generalised } \\
\text { anthropomorph }\end{array}$ & & black & & & male \\
\hline 61 & $\begin{array}{l}\text { linear non- } \\
\text { figurative }\end{array}$ & & black & & & \\
\hline 62 & $\begin{array}{l}\text { linear non- } \\
\text { figurative }\end{array}$ & & red & & & \\
\hline
\end{tabular}


Appendix 1. Continued

\begin{tabular}{|c|c|c|c|c|c|c|}
\hline $\begin{array}{c}\text { Picture } \\
\#\end{array}$ & Motif type & Engraving & $\begin{array}{c}\text { Drawing or } \\
\text { painting colour }\end{array}$ & $\begin{array}{l}\text { Maximum } \\
\text { length } \\
\text { (cm) }\end{array}$ & $\begin{array}{l}{ }^{14} \mathrm{C} \text { date } \\
\text { (BP) }\end{array}$ & Comments \\
\hline 63 & $\begin{array}{l}\text { linear non- } \\
\text { figurative }\end{array}$ & & red & & & \\
\hline 64 & $\begin{array}{l}\text { linear non- } \\
\text { figurative }\end{array}$ & & red & & & \\
\hline 65 & $\begin{array}{l}\text { linear non- } \\
\text { figurative }\end{array}$ & & red & & & \\
\hline 66 & $\begin{array}{l}\text { linear non- } \\
\text { figurative }\end{array}$ & & red & & & \\
\hline 67 & $\begin{array}{c}\text { generalised } \\
\text { anthropomorph }\end{array}$ & & black & & & \\
\hline 68 & $\begin{array}{c}\text { generalised } \\
\text { anthropomorph }\end{array}$ & & black & & & male \\
\hline 69 & $\begin{array}{c}\text { generalised } \\
\text { anthropomorph }\end{array}$ & & black & & & male \\
\hline 70 & $\begin{array}{c}\text { generalised } \\
\text { anthropomorph }\end{array}$ & & black & & & male \\
\hline 71 & $\begin{array}{c}\text { generalised } \\
\text { anthropomorph }\end{array}$ & & black & & & male \\
\hline 72 & $\begin{array}{c}\text { generalised } \\
\text { anthropomorph }\end{array}$ & & black & & & male \\
\hline 73 & $\begin{array}{c}\text { generalised } \\
\text { anthropomorph }\end{array}$ & & black & & & male \\
\hline 74 & $\begin{array}{l}\text { linear non- } \\
\text { figurative }\end{array}$ & & black & & & \\
\hline 75 & $\begin{array}{l}\text { linear non- } \\
\text { figurative }\end{array}$ & & black & & & \\
\hline 76 & indeterminate & & black & & & \\
\hline 77 & $\begin{array}{c}\text { generalised } \\
\text { anthropomorph }\end{array}$ & & black & & & male \\
\hline 78 & indeterminate & & black & & & \\
\hline 79 & $\begin{array}{l}\text { linear non- } \\
\text { figurative }\end{array}$ & & red & & & \\
\hline 80 & radiating lines & & red & & & \\
\hline 81 & $\begin{array}{c}\text { generalised } \\
\text { anthropomorph }\end{array}$ & & black & & & \\
\hline 82 & $\begin{array}{c}\text { generalised } \\
\text { anthropomorph }\end{array}$ & & black & & & \\
\hline 83 & $\begin{array}{c}\text { generalised } \\
\text { anthropomorph }\end{array}$ & & black & & & \\
\hline 84 & indeterminate & & black & & & \\
\hline 85 & $\begin{array}{l}\text { linear non- } \\
\text { figurative }\end{array}$ & & black & & & \\
\hline 86 & $\begin{array}{c}\text { generalised } \\
\text { anthropomorph }\end{array}$ & & black & & & \\
\hline 87 & $\begin{array}{l}\text { linear non- } \\
\text { figurative }\end{array}$ & & black & & & \\
\hline 88 & $\begin{array}{c}\text { generalised } \\
\text { anthropomorph }\end{array}$ & & black & & & male \\
\hline 89 & $\begin{array}{l}\text { linear non- } \\
\text { figurative }\end{array}$ & & black & & & \\
\hline 90 & indeterminate & & black & & & \\
\hline 91 & $\begin{array}{l}\text { linear non- } \\
\text { figurative }\end{array}$ & & black & & & \\
\hline
\end{tabular}


Appendix 1. Continued

\begin{tabular}{|c|c|c|c|c|c|c|}
\hline $\begin{array}{c}\text { Picture } \\
\#\end{array}$ & Motif type & Engraving & $\begin{array}{c}\text { Drawing or } \\
\text { painting colour }\end{array}$ & $\begin{array}{l}\text { Maximum } \\
\text { length } \\
\text { (cm) }\end{array}$ & $\begin{array}{l}{ }^{14} \text { C date } \\
\text { (BP) }\end{array}$ & Comments \\
\hline 92 & indeterminate & & black & & & \\
\hline
\end{tabular}

